\title{
Comparison of carbon balance measuring tools in an enhanced oil recovery project based on the carbon dioxide from the ammonia production process streams
}

\author{
Miguel Angel Morales Mora ${ }^{1}$, Froebel Carlos Pretelín Vergara C. ${ }^{2}$, Sergio Alejandro \\ Martínez Delgadillo ${ }^{3}$ and Miguel Antonio Leiva ${ }^{4}$
}

\begin{abstract}
A number of studies addressing the environmental impact of deploying carbon capture utilization and storage are focused on sources of $\mathrm{CO}_{2}$ in the power sector. However, there is a lack of environmental studies on the use of $\mathrm{CO}_{2}$ from process stream within the oil and gas industries. The carbon balance of an enhanced oil recovery project for the specific case of using $\mathrm{CO}_{2}$ process stream of ammonia production from emission factors and regional databases in the Mexican oil and gas sector was assessed. Two independent tools to assess life cycle assessment according to guidelines ISO 14040/14044 were utilized: (i) use of Umberto software to quantify the environmental impact with ReCiPe model midpoint; and, (ii) The American Petroleum Institute method through the use of emissions factor for each source and emission gas of the activity/facility in a spread sheet. The results of the tools were compared and the dissimilarities analysed. The emissions profiles from all direct and indirect activities associated with the enhanced oil recovery system were compared with a "cradle-to-grave" model. The functional unit is one barrel of crude oil extracted and consumed. Global warming as the environmental indicator of both tools was used. Additionally, the energy balance of the project was estimated. The global warming impact of the enhanced oil recovery system was $0.51 \mathrm{tCO}_{2 \mathrm{e}} / \mathrm{barrel}(\mathrm{bbl})$ using the American Petroleum Institute tool, whilst the emissions using Umberto software were $0.54 \mathrm{tCO}_{2 \mathrm{e}} / \mathrm{bbl}$. Also, for each MJ of energy produced a value of $72 \mathrm{tCO}_{2 \mathrm{e}} / \mathrm{MJ}$ oil and of $66 \mathrm{tCO}_{2 \mathrm{e}} / \mathrm{MJ}$ oil, were obtained. This study demonstrates that both tools delivered an accurate estimation of the greenhouse gas emissions in the enhanced oil recovery system for the oil and gas industries. However, American Petroleum Institute has the advantage that the calculations can be performed 'manually' in a spread sheet using emissions factor adjusted to the facilities and Country. Regarding the results of both tools, this work shows that American Petroleum Institute results have proven to be an efficient tool for practitioners and researchers that intend to analyse the greenhouse gas emission of carbon capture utilization and storage systems to estimate, with accuracy, the global warming impact.
\end{abstract}

Key words: Ammonia production, crave to grave model, carbon balance, global warming impact 


\section{Introduction}

The number of studies addressing the environmental impact of deploying carbon capture and utilization (CCU) and/or carbon capture and storage (CCS) is rather limited and focuses on sources of $\mathrm{CO}_{2}$ from the power sector (Corten et al., 2013). Moreover, CCS from industrial applications has so far received little attention, despite International Energy Agency-United Nations Industrial Development Organization, IEA-UNIDO (2011) highlighting that $\mathrm{CO}_{2}$ emissions should be reduced up to 4.0 gigatonnes (Gt) annually by 2050. The CCS studies suggest that the global warming (GW) resulting from power plants needs to be reduced (Leung et al., 2014).

Many studies marginally discuss different aspects (Cuellar-Franca and Azapagic, 2015) when assessing the environmental performance of power plants with CCS and CCU, despite the difficulty in directly comparing the relative importance of upstream (e.g. coal mining, coal transport, monoethanolamine production), as mentioned by Corsten et al. (2013), and downstream emissions (e.g. $\mathrm{CO}_{2}$ capture). This emphasises the need for optimal designs in all the value chains. Nevertheless, as the available recent literature aiming to address the life cycle assessment (LCA) of CCS focuses on different technologies, as well as system boundaries; database sources, transparency in the data reported and specific assumptions are not clearly evident in the studies. This makes it even more difficult to draw robust conclusions on the potential environmental impact of CCS and CCU. Marx et al. (2011) gave a synthesis report about LCA-CCS evaluations, in which some shortcomings in the studies' underlying assumptions and methodologies were found. Petrakopoulou and Tsatsaronis (2014) established that the principal aim of CCUS technology is how their environmental impact can be reduced and energy efficiency maximized. Consequently, a valuable way to assess the LCA of enhanced oil recovery operations is to review the carbon emissions profile for the whole operation, and compare this with projects of $\mathrm{CO}_{2}$ storage profile.

This subject is important since frequently the LCA practitioner will not find one obvious choice among a number of different databases or calculation methods, and the question, therefore naturally arises: "Does my choice of method or database have any influence on the conclusions?". Based on simulation results and process configuration of the CCS system, the LCA method has been applied to evaluate the environmental impact of the system taking into account the complete life cycle from raw material to $\mathrm{CO}_{2}$ injection or refinery product combustion from commercial software (von der Assen, et al., 2014). In addition, the life cycle inventory (LCI) calculations could involve either the whole system boundary or not, and include different raw materials (coal and natural gas) or only main stages of the LCA, i.e. a gross inventory, without going into the details of each stage from extraction of raw material to use. Therefore, system boundary or expanded system boundaries and their stages are neither clearly specified nor detailed, generating different results of net emission per barrel of oil in the enhanced oil recovery (EOR) system (Cuellar-Franca and Azapagic, 2015). Specific to the oil and gas industries, there is a lack of direct measurements, or offshore/onshore monitoring of emission gases is rare, and so for most sources only the activity data, such as fuel consumption or the rate of a process activity are available. When direct measurement systems are not in place, the calculation of emissions can be made from an activity factor (Stewart and Haszeldine, 2014). 
The most commonly practiced CCS approach, in terms of $\mathrm{CO}_{2}$ sequestered, is $\mathrm{CO}_{2}$ enhanced oil recovery $\left(\mathrm{CO}_{2}-\mathrm{EOR}\right)$. The $\mathrm{CO}_{2}$ injection from natural sources for EOR has been applied commercially since the early 1970s in the United States for oil recovery, typically in no longer productive mature fields. However, today EOR operations are carried out with the aim of maximizing oil output with the minimum $\mathrm{CO}_{2}$ injection (International Energy Agency, EIA, 2015).

According to Leach et al. (2011), approximately 30-40\% of the $\mathrm{CO}_{2}$ injected during a single injection usually remains trapped in the reservoir. This value is similar to that reported in the first $\mathrm{CO}_{2}$-EOR case study in Mexico performed at the Artesa reservoir in the Chiapas and Tabasco states, where $40 \%$ of $\mathrm{CO}_{2}$ injected was stored (Leon-Garcia et al. 2015).

As with any secondary recovery methods, additional energy is consumed in the $\mathrm{CO}_{2}$ capture, resulting in a higher environmental impact per $\mathrm{MWh}$ than without $\mathrm{CO}_{2}$ capture (Petrakopoulou and Tsatsaronis, 2014). The production of additional oil will be $\mathrm{CO}_{2}$-EOR that, when combusted will generate additional $\mathrm{CO}_{2}$ emissions (Jaramillo et al. 2009). Along with this, there is a discussion as to whether these technologies can provide products that sequester the $\mathrm{CO}_{2}$ for a long or short period (Electric Power Research Institute, EPRI, 2013), how much $\mathrm{CO}_{2}$ is really sequestrated by each technology, and if CCS should be considered as a mitigation technology (Armstrong and Styring, 2015). Thus, climate change mitigation and long-term $\mathrm{CO}_{2}$ storage goals are not principal drivers for EOR projects (IEA, 2015). EOR also sequesters $\mathrm{CO}_{2}$ in the process with potential climate benefits. An important portion of the injected $\mathrm{CO}_{2}$ remains in place, a technology that has been proved in USA (Dai et al., 2014a) and Canada with the world's first commercial scale postcombustion coal fired carbon capture and storage in the Saskatchewan Project (Stéphenne, 2014). All studies show a substantial reduction of greenhouse gas (GHG) emissions from power production, in the order of 40-97\% (Corsten et al., 2013). According to CuellarFranca and Azapagic (2015), the reduction in the global warming potential (GWP) is sensitive to $\mathrm{CO}_{2}$ capture and allocation methods as well as the assumptions for heat recovery from the system.

IEA-UNIDO (2011) published a Technology Roadmap CCS in industrial applications providing an outlook of industrial CCS up to 2050, where high-purity $\mathrm{CO}_{2}$ sources like ethylene oxide and ammonia production were included in this roadmap.

The 2014 global status of CSS projects states that four projects are in operation from $\mathrm{CO}_{2}$ fertilizer plants: three for EOR and one as geological storage, with a contribution of 4.5-5.1 $\mathrm{MtCO}_{2}$ /year (Global CCS Institute, 2015). These values represent a marginal fraction of the total anthropogenic emission (32,000 $\mathrm{Mt} \mathrm{CO}_{2} / \mathrm{y}$ ) by this sector (Armstrong and Styring, 2015). In 2014, the start up operation of the commercial North Burbank Unit (NBU), in Kansas-Oklahoma USA, CCU and the CCS (EOR) from a fertilizer-urea plant (National Energy Technology Laboratory, NETL, 2015) were included.

The United Stated Environmental Protection Agency (USEPA) lists 22 ammonia manufacturers in the United States. Eighteen of these are capturing $\mathrm{CO}_{2}$ as a by-product and selling it as an industrial product to the market (USEPA, 2015). NETL (2013a) published a report on alternative sources of $\mathrm{CO}_{2}$, documenting a cradle-to-gate footprint per unit of $\mathrm{CO}_{2}$ produced from ammonia production. This study has not found cradle-to-grave life cycle results published on EOR production from $\mathrm{CO}_{2}$ by ammonia plants. There are not many references in the literature describing the use of LCA-CCS studies in petrochemical processes or the oil refinery (Nagashima et al., 2011). 
Consequently, this work was motivated by the need within the oil and gas sectors, to analyse and compare the results of other methodological models, to identify environmental "hot spots" in the LCI calculations of the CCUS-LCA studies. This study might therefore suggest potential improvement actions to enable a reduction in the environmental impact of the upstream and downstream processes of the oil and gas industries, as well as to assist LCA practitioners to compare the results when they use the CCUS system using regional or local databases.

\subsection{Overview of CCUS in Mexico}

The Mexican Government recently published the CCUS Technology Roadmap recognizing the need for $\mathrm{CCS}$ to aid in reaching the $\mathrm{CO} 2$ reduction goal in view of the fast growth in electricity demand in the country (Energy Secretariat, SENER, 2014). According to this study, it is estimated that Mexico has a theoretical capacity for storing $100 \mathrm{Gt}$ of $\mathrm{CO}_{2}$. If it were considered that the $\mathrm{CO}_{2}$ annual emissions in Mexico in 2012 represented an equivalent of $0.74 \mathrm{Gt}$, then the maximum storage capacity in the country would be reached in 135 years.

A recent update of the 2013 GHG inventory showed that emissions from the oil and gas sectors in Mexico accounted for $12 \%$ of total GHG emissions at the national level, i.e. 80,455 Gt CO2e/y (Secretariat of Environment and Natural Resources-National Institute of Ecology and Climate Change, SEMARNAT-INECC, 2016). Of this, 20\% is generated in the states of Veracruz and Tabasco, where mature fields are located and would require large amounts of $\mathrm{CO} 2$ for EOR. For instance, it is estimated that the bigger Mexican oil fields candidates for EOR would need up to 50 million metric tons of $\mathrm{CO}_{2}$ per year in the Gulf of Mexico (Lacy et al., 2012). Petróleos Mexicanos (PEMEX) Sustainability Report, (2014), affirms that 14.7 million metric tons $\mathrm{CO}_{2} /$ year were emitted from fuel combustions, 1.4 million metric tons $\mathrm{CO}_{2}$ /year were produced by venting gas from three ammonia plants' processes, and 0.9 million metric tons $\mathrm{CO}_{2}$ /year from one hydrogen plant in the Southeast of Mexico (Southeast of the states of Veracruz and Tabasco) (Figure 1).

Specifically, the Cinco Presidentes Oil asset (CPOA) with a 0.085 million barrel (bbl) a day production of domestic oil (20-35 API) (PEMEX, 2015) has been classified as an inclusion zone (D) for the geologic storage of $\mathrm{CO}_{2}$ (Dávila et al., 2010). In the case of employing $\mathrm{CO}_{2}$ for EOR, the ammonia plant from Cosoleacaque Petrochemical Complex (CPC) has the advantage of being located only 50-70 km from the CPOA. It is the closest $\mathrm{CO}_{2}$ source for implementing the technology of EOR in Mexico, with a total 2P volume (Proven and probable reserves) of 249.9 billion barrels of oil reserves, with 565 wells in operation (National Hydrocarbons Commission, CNH, 2016).

\section{INSERT FIGURE 1 HERE}

The Brillante oil field is a young field, having been in operation for three years, located within the CPOA (Table 1) with a production of less than $3,000 \mathrm{bbl} / \mathrm{d}$ of $35^{\circ} \mathrm{API}$ (ArteagaCardona et al., 2015).

\section{INSERT TABLE 1 HERE}

\section{2. $\mathrm{CO}_{2}$ source: Ammonia process from $\mathrm{CPC}$}


Ammonia production depends on natural gas (NG) both as a feedstock and as a fuel. Haas and van Dijk (2010) estimated the average energy consumption for ammonia $\left(\mathrm{NH}_{3}\right)$ production in Europe to be around $34.7 \mathrm{GJ} / \mathrm{t}$ with 1.5 tons of $\mathrm{CO}_{2} / \mathrm{t}$ of ammonia emitted to the atmosphere during production. Williams and Al-Ansari (2007) determined a global average energy consumption of $36.9 \times 10^{3} \mathrm{MJ} / \mathrm{t}$. Makhlouf et al. (2015) estimated a Cumulative Energy Requirement (CER) of $51.945 \times 10^{3} \mathrm{MJ} / \mathrm{t}$ of ammonia and $1.44 \mathrm{t}$ $\mathrm{CO}_{2 \mathrm{eq}} / \mathrm{t}$ of ammonia for an ammonia plant taking into account the $\mathrm{CO}_{2}$ in the flue gas in Algeria.

In Mexico, the NG comes from an offshore platform located in the Southeast of the Gulf of Mexico at $500 \mathrm{~km}$ distance from the CPC. For synthetic ammonia production there are six principal process steps from NG feedstock (Figure 2). The primary reforming step converts methane $\left(\mathrm{CH}_{4}\right)$ to $\mathrm{CO}_{2}$, carbon monoxide $(\mathrm{CO})$, and hydrogen $\left(\mathrm{H}_{2}\right)$ in the presence of a catalyst. Only 30 to 40 per cent of the $\mathrm{CH}_{4}$ feedstock to the primary reformer is converted to $\mathrm{CO}$ and $\mathrm{CO}_{2}$ in this step of the process. The secondary reforming step converts the remaining $\mathrm{CH}_{4}$ feedstock to $\mathrm{CO}$ and $\mathrm{CO}_{2}$. The $\mathrm{CO}$ from the secondary reforming step (representing approximately 15 per cent of the process gas) is converted to $\mathrm{CO}_{2}$ in the presence of a catalyst, water, and air in the shift conversion step. $\mathrm{CO}_{2}$ is removed from the process gas by the shift conversion process; the hydrogen is combined with the nitrogen $\left(\mathrm{N}_{2}\right)$ gas in the process gas during the ammonia synthesis step to produce ammonia. The $\mathrm{CO}_{2}$ is incorporated to a waste gas stream with other process impurities and absorbed by a scrubber solution (Overcash et al., 2007).

The $\mathrm{CO}_{2}$ emissions from four ammonia plants (AP) of the CPC, producing 480,000 tNH $3 / y$ and 497,000 $\mathrm{tCO}_{2} / \mathrm{y}$ as by-product with $98 \%$ purity, were considered as supply for the EOR project in this study. Currently, the $\mathrm{CO}_{2}$ produced is employed to produce urea and for the beverage industry. Of the remainder currently emitted into the atmosphere (Figure 2), PEMEX plans to use $834 \mathrm{t} / \mathrm{d}$ of this $\mathrm{CO}_{2}$ for EOR in the Brillante field (Arteaga-Cardona et al., 2015).

\section{INSERT FIGURE 2 HERE}

A considerably lower energy is required to separate and capture the $\mathrm{CO}_{2}$ from ammonia production. For instance, AP from $\mathrm{CPC}$ is $1.35 \mathrm{MJ} / \mathrm{kgCO}_{2}$, which is lower than in the power sector (2.8 to $4.2 \mathrm{MJ} / \mathrm{kgCO}_{2}$ ) $\mathrm{CO}_{2}$ capture technologies (Luis, 2015). The $\mathrm{CO}_{2}$ is removed in a tower with several beds through absorption (pre-combustion) employing $30 \%$ solutions of potassium carbonate $\left(\mathrm{K}_{2} \mathrm{CO}_{3}\right)$, using heat integration in their facilities. The AP from CPC has an emission factor of 1.4 metric tons $\mathrm{CO}_{2} /$ metric ton $\mathrm{NH}_{3}$. Therefore, the use of $\mathrm{CO}_{2}$ that is currently vent into the atmosphere by the ammonia plant and close to mature oil fields as the CPOA, could substantially improve the environmental profile of the plant and energy of the EOR project.

\section{Materials and methods}

The CCUS technology was considered here as an end-of-life process, so that it can be integrated to any industrial plant that is an anthropogenic source of $\mathrm{CO}_{2}$. Therefore, the product category was defined either as a system of technologies that integrate the $\mathrm{CO}_{2}$-EOR project's three stages: carbon dioxide $\left(\mathrm{CO}_{2}\right)$ capture (pre-combustion), transport $\left(\mathrm{CO}_{2}\right)$ and 
storage (oil and gas reservoirs) or as utilization (EOR) services (Strazza et al., 2013), using process streams from the AP as a source of $\mathrm{CO}_{2}$.

\subsection{Objective and scope of study}

The objective of this study was to assess the impact of GHG emissions and energy balance of the Brillante $\mathrm{CO}_{2}$-EOR project, located in the CPOA in the southeast of Mexico, using $\mathrm{CO}_{2}$ process streams from ammonia production, and to compare the single environmental impact: resulting global warming $(\mathrm{GW})$ contrast. Two independent tools to assess life cycle analysis (LCA) according to ISO 14040/14044 guidelines were compared: Umberto software (US) versus American Petroleum Institute (API) calculations through a spreadsheet, with EF adjusted to Mexico. Additionally, to identify environmental hotspots and to suggest potential improvement actions that would reduce the environmental impact of the CCUS system.

The study considered the stages from the extraction of natural gas as feedstock for producing ammonia, to the combustion of the refined petroleum. The studied system operates at six subsystems involving different industrial sites, separated by nearly $500 \mathrm{~km}$ which requires the transport of gas and oil by pipeline (Figure 3).

\section{INSERT FIGURE 3 HERE}

\subsubsection{System boundary}

To facilitate the identification of impact sources, the system was divided into six subsystems: (i) gas extraction, (ii) gas processing (iii) ammonia production, (iv) EOR operation, (v) refining process and (vi) refinery product's combustion (Table 2). Figure 4 shows the system boundary for the whole Brillante $\mathrm{CO}_{2}$-EOR system. The GHG emissions associated with the life cycle of the project include the emissions from the offshore based oil producing platform (Cantarell), located in the southeast marine region in the Gulf of Mexico, to the Refinery product's combustion (e.g. gasoline) i.e. "cradle-to-grave" model (Figure 4). Material and energy flow network of process system is shown in Supporting Information (SI) Figure SI-1.

\section{INSERT TABLE 2 HERE}

Expanded system boundary and displacement was used to sum the GHG emissions for both methodologies according to table 2 and figure 4, and also for the ammonia product and $\mathrm{CO}_{2}$ as by-product generated in accordance with ISO standards 14040-14044 (ISO, 2006 a, b).

\section{INSERT FIGURE 4 HERE}

The boundaries excluded transport of refined petroleum products from the refinery to the consumer, since emissions from transporting these products represent less than $1 \%$ of the lifecycle emissions, Wang et al. (2008). In addition, this study also omits the associated 
emissions for the infrastructure necessary for the construction of the $\mathrm{CO}_{2}-\mathrm{EOR}$ because Brillante field already exists.

\subsubsection{Functional unit (FU)}

Considering that the purpose of the Brillante $\mathrm{CO}_{2}$-EOR project is to capture $\mathrm{CO}_{2}$ and employ it in the oil recovery process, for both methodologies, the FU was defined as one barrel of crude oil extracted and consumed.

\subsection{Life cycle inventory (LCI)}

In order to build and compare the LCIs with both tools, this study was conducted in accordance with ISO standards for LCA ISO 14040 and ISO 14044 (ISO, 2006 a, b).

The LCI includes direct (combustion) and indirect emissions, fugitive emissions (leaks in facilities and pipeline, oil and gas fields) and venting processes; i.e. the direct activities related to exploration, production, gas processing, transportation, distribution and refining by the oil and gas industries (Table 2).

The inventory data were collected from the PEMEX 2015 database to obtain the GHG emissions from assets over which PEMEX has $100 \%$ operational control. The characterization of GHG emissions of each stage/activity was made with an up-bottom approach. The uncertainty of the data from upstream and downstream operations to build LCI was evaluated. The data have a confidence interval of $95 \%$. The stage of the direct emissions (combustion and indirect) corresponds to the estimated for the manufacturing processes from PEMEX data. The non-combustion emissions (gas transmission pipeline and $\mathrm{CO}_{2}$ transport, pipeline leaks, process vents) were estimated according to the EF established by American Petroleum Institute, API (2009), as well as the API SPEC 5L: Specification for Line Pipe, for the emission factor of the $\mathrm{CO}_{2}$ transport (API, 2011). It was considered necessary to remove $1,355 \mathrm{Nm}^{3}$ /day of natural gas for each ton of $\mathrm{NH}_{3}$ in the CPC, which is equivalent to $0.0077 \%$ of the total NG production at Cantarell, to establish the amount of natural gas to be subtracted from the offshore platform Cantarell for the $\mathrm{CP}$ $\mathrm{CO}_{2}$-EOR project. Finally, it was necessary to do the correction for the actual composition of methane in the handled gas, and therefore $\mathrm{CO}_{2}$ emissions were calculated by the ratio of methane $\left(\mathrm{CH}_{4}\right)$ to $\mathrm{CO}_{2}$ in the gas produced. Table 3 shows the key input parameters utilized in the model of the $\mathrm{CO}_{2}$-EOR project.

\section{INSERT TABLE 3 HERE}

\subsubsection{Establishment and guide calculation:}

\section{a) API}

The LCI emissions were calculated according to Table SI-1 (Supporting Information) and reported in $\mathrm{CO}_{2}$-equivalent $\left(\mathrm{CO}_{2 \mathrm{e}}\right)$ units. Section 3-technical considerations of the Compendium of GHG methodologies for the oil and natural gas industry (Americam PI, 2009) were used to obtain the results of the GW. The calculation of emissions where direct 
monitoring results are not available involves the use of an activity factor, such as fuel consumption or flow to flare/vent, and an emission factor for each source (s) and emission gas (i). By multiplying the activity factor (AF) by the emission factor (EF), the masses of emission gas can be calculated. Equation 1 results from applying Table SI-1 to obtain the GHG inventory of the six subsystems, i.e. the sum of all the emissions for a particular facility used:

$$
\mathrm{M}(\mathrm{is})=\mathrm{EF}(\mathrm{is}) \bullet \mathrm{AF}(\mathrm{s})
$$

Equation (1)

Where:

$\mathrm{M}$ (is) = is the emitted mass of a particular emission gas (i) for a given source (s); EF (is) = is the emission factor for the emission gas (i) relevant to the emission source (s); AF (s) is the source (s) activity factor.

To calculate $\mathrm{CO}_{2 \mathrm{e}}$, equation 2 was used and incorporated in Table SP-1.

$$
\left.\mathrm{CO}_{2 \mathrm{e}} \text { tonnes }=\sum_{i=1}^{\# \text { Greenhause Gas Species }} \text { (tonnes } \mathrm{i} \cdot \mathrm{GWP}_{\mathrm{i}}\right)
$$

Equation (2)

Where:

$\mathrm{CO}_{2 \mathrm{e}}=$ carbon dioxide equivalent emissions (ton); tonnesi $=\mathrm{GHG}$ emissions of pollutant $i$ (tonnes); and $\mathrm{GWP}_{\mathrm{i}}=$ global warming potential of pollutant i. (i.e. $\mathrm{CO}_{2}$, (1), $\mathrm{CH}_{4}(25), \mathrm{N}_{2} \mathrm{O}$ (298)) (tonnes $\mathrm{CO}_{2 \mathrm{e}}$ per ton i).

An emission factor (default and calculated from tables of API or another source) represents an average emission rate for a given source, and is generally expressed as a mass or volume of emissions per source type or measure of activity related to the source.

As shown in Table SI-1, step 1 consists of making a list of number of facilities and type of activity GHG emissions (columns a and b), step 2 add the EF (column c) for type of activity and step 3 multiply and add up to the total emissions as $\mathrm{CO}_{2 \mathrm{e}}$ (column i).

\section{b) Umberto software (US)}

In the construction of LCI for US, the next step was to adjust the input/output material and then process the six subsystems in Umberto according to the EF of Table 3, as well as the composition and amount of natural gas, to estimate GHG emissions as $\mathrm{CO}_{2 \mathrm{e}}$ for the $\mathrm{CO}_{2}$-EOR project.

\subsubsection{Displacement and allocation of coproduct management}

Systems operations produce ammonia and $\mathrm{CO}_{2}$, in addition to petroleum as by-products. Thus system boundary expansions and displacements were used to allocate lifecycle GHG emissions between petroleum and ammonia (ISO, 2006b).

Given the process characteristics, in which the NG functions as feedstock and fuel, the proportion of mass for each activity was used as a method of assignment, with the aim of reflecting the value of the ammonia product and the $\mathrm{CO}_{2}$ as subproduct. Since the production of 1 ton of ammonia requires $1,355 \mathrm{NM}^{3}$ of $\mathrm{NG}$ consumption (Feedstock + fuel), generating $\mathrm{CO}_{2}$ as a by-product (Table 4), the amount of feedstock consumed in the 

of ammonia displaced by the system, representing the emissions credits (Figure 4).

\section{INSERT TABLE 4 HERE}

Therefore, an allocation factor of $55.2 \%$ was subtracted or considered as emissions avoided and used for displacement.

Negative emissions (credits) associated with geological sequestration of $\mathrm{CO}_{2}$ during EOR were calculated based on storage factor reported by Hussaint et al. (2013) and corresponding to about $0.20 \mathrm{tCO}_{2 \mathrm{e}} \mathrm{/bbl}$.

\subsection{Impact assessment of API and US}

The life cycle of GHG emissions was quantified using "global warming" (GW), expressed in emissions of $\mathrm{CO}_{2}$ equivalent $\left(\mathrm{CO}_{2 \mathrm{e}}\right)$ as the environmental indicator. The life cycle is considered as the established FU for both API and US.

The mandatory and optional elements of the LCA according to ISO 14040 were used in both methodologies. The time horizon resulting from the use of primary and secondary energy from fossil fuels: (1) time horizon characterization (for calculating GWPs) and (2) time period of assessment (the period over which GHG emissions and removals from a product system) was considered (Levasseur, 2015). The main impact category analysed in this study was GW expressed in emissions of equivalent $\mathrm{CO}_{2}\left(\mathrm{CO}_{2 \mathrm{e}}\right)$ and referred to the established FU: one barrel of crude oil extracted and consumed for both tools.

API. Analytically, with the application of equations 1 and 2 in Table SI-1, the $\mathrm{CO}_{2}$ and methane $\left(\mathrm{CH}_{4}\right)$ emissions were calculated and reported as $\mathrm{CO}_{2 \mathrm{e}}$ (see first column to the right) using 100-year GWP (Intergovernmental Panel Climate Change, IPCC, 2007) as well as for that established by API (2009) and the Project's nine year lifetime (CCS phase) (Arteaga-Cardona et al., 2015). This time period was adopted for both tools given that $\mathrm{CO}_{2}$ is the main contributing pollutant. It is important to manage the risk of $\mathrm{CO}_{2}$ migration through monitoring, verifying and reporting (Bandza and Vajjhala, 2014), given the $\mathrm{CO}_{2}$ stored by the $\mathrm{CO}_{2}$-EOR operation. Lastly, the aim is to confirm that combining $\mathrm{CO}_{2}$-EOR with storage integrity is a promising strategy for GHG reduction.

US. The environmental impacts were quantified by LCA applying Umberto Universal 5.3 software based on the ReCiPe methodology (Goedkoop et al., 2009) and Ecoinvent 2.2 database of material in Umberto. The model of ReCiPe used for this $\mathrm{CO}_{2}$-EOR system included the application of life-cycle of fossil fuel GHG emissions, involving six subsystems. In this sense, LCA studies have already been employed for the assessment of the CCS technology, which have used ReCiPe Method with Umberto software (Xiao et al., 2013), and Volkart et al. (2013) with SimaPro v7.3.3 software.

Finally, lifecycle GHG emissions and inputs/outputs for $\mathrm{CO}_{2}-\mathrm{EOR}$ as metric tons of $\mathrm{CO}_{2}$ equivalent emissions per barrel of crude oil extracted $\left(\mathrm{tCO}_{2 \mathrm{e}} / \mathrm{bbl}\right)$ for both tools in each process step, as well as net GHG emissions, are presented to ensure net emission reduction and allow the addressees to evaluate directly a set of relevant inventory data for capture and storage (EOR/CCS) activities, together with a measure of the performance of the whole process.

\section{Results and discussion}




\subsection{Life Cycle GHG $\mathrm{CO}_{2}$-EOR project}

Table 5 shows the results of the net GHG emissions for each of the six subsystems and the sixteen steps, along with assessment of results between both tools in $\mathrm{CO}_{2}$-EOR. For each process step, the values are reported as metric tons of $\mathrm{CO}_{2 \mathrm{e}}$ per barrel of oil extracted $\left(\mathrm{tCO}_{2 \mathrm{e}} / \mathrm{bbl}\right)$. The total emissions represent the carbon footprint (i.e. $\mathrm{GW}$ ) for the whole chain.

\section{INSERT TABLE 5 HERE}

The GW impact estimated by the API together with the life cycle analysed was 0.88 $\mathrm{tCO}_{2 \mathrm{e}} / \mathrm{bbl}$, only $2.0 \%$ higher than US $\left(0.85 \mathrm{tCO}_{2 \mathrm{e}} / \mathrm{bbl}\right)$. These results do not consider displacement and allocation of emissions. No significant differences between both tools by subsystems or stages were found.

In subsystem III, representing the production of ammonia and transport of $\mathrm{CO}_{2}$ to the Brillante $\mathrm{CO}_{2}$-EOR project, the average estimation of $\mathrm{GW}$ was of $0.266 \mathrm{tCO}_{2 \mathrm{e}} / \mathrm{bbl}$, with a contribution of $30.8 \%$ of the total emissions (Table 5). These emissions would be generated by ammonia production, compression (electricity), transport and fugitive emission of the total GHG emissions. Subsystems II and V, the operation units, provided the lower emissions. The upstream emissions from the NG extraction on the offshore platform in Cantarell to NG processing were $4.4 \%$. This value is 126.7 times higher than that of upstream emissions reported for Natural gas $\mathrm{NGCC} \mathrm{CO}_{2}$-EOR, but with values almost similar to the Coal SNG plant $\mathrm{CO}_{2}$-EOR values of $0.02 \mathrm{tCO}_{2 \mathrm{e}} / \mathrm{bbl}$ (Hussaint et al., 2013). Lacy et al. (2015) found a GWP impact for this stage of $0.139 \mathrm{tCO}_{2 \mathrm{e}} / \mathrm{bbl}$, which included construction, operation and dismantling of pipelines and oil wells activities.

Figure 5 shows the GHG emissions by principal activities. Both LCA-US and API identify that both refinery combustion products and transformation processes represent $50.7 \%$ and $30.8 \%$ of the total GHG emission, representing $81.5 \%$ of the net direct emissions, with similar values in both methodologies. This result was comparable to the GHG emissions of a $\mathrm{CO}_{2}$-EOR case in the power sector, since the majority of the emissions are from combustion of refined petroleum products (Venkatesh et al., 2011). Additionally, some studies assume that EOR crude from fossil $\mathrm{CO}_{2}$ is less $\mathrm{CO}_{2}$ intensive than EOR crude from natural dome $\mathrm{CO}_{2}$, albeit with the same efficiency of production regardless of $\mathrm{CO}_{2}$ source (Cooney et al., 2015).

The remainder $(18.5 \%)$ corresponds to other activities. In the upstream emissions, this study found more contrasting results for each of the methodologies used than LCA-CCS studies calculating $\mathrm{CO}_{2}$ resulting from power generation.

\section{INSERT FIGURE 5 HERE}

The contributions by transport and compression were $2 \%$ of the net emissions, with $\mathrm{CO}_{2}$ representing $72 \%$ and methane $28 \%$. These values agree with those reported by Zapp et al. (2012). The length of the pipeline has the smallest effect. Spath and Mann (2004) estimated a share of transport on total GW increasing from $0.1 \%$ for $300 \mathrm{~km}$ to $1 \%$ for $1800 \mathrm{~km}$ pipeline length.

Table 6 shows that for each MJ used to produce energy from the $\mathrm{CO}_{2}$-EOR project, 66 $\mathrm{tCO}_{2 \mathrm{e}} / \mathrm{MJ}$ oil are emitted in US, whilst the API predicts that, on average the emissions were 

this project, only $1 \%$ of the total energy generated would be required to produce one barrel. On the other hand, this result is $36.2 \%$ higher when compared to that obtained by Lacy et al. (2015) from a hypothetical CCUS case in a natural gas combined cycle power plant (NGCC). They reported values of $44.0 \mathrm{tCO}_{2 \mathrm{e}} / \mathrm{MJ}$.

\section{INSERT TABLE 6 HERE}

It is important to point out that $1,350 \mathrm{MJ} / \mathrm{tCO}_{2}$ are needed to capture one ton of $\mathrm{CO}_{2}$ as by-product at the ammonia plant, 58\% lower than that reported from thermal generation processes of electricity with $\mathrm{CO}_{2}$ capture (Rochelle et al., 2011). As 4,632 tCO $2 / \mathrm{d}$ could be sent into the atmosphere in the four ammonia plants from the CPC, then primary energy is being wasted to the equivalent of $6,253,2 \mathrm{GJ} / \mathrm{d}$, a loss of primary energy that could generate $980 \mathrm{bbl} / \mathrm{d}$.

Table 7 provides the input/output results expressed in metric tons of $\mathrm{CO}_{2 \mathrm{e}}$ emissions per barrel of crude oil extracted $(\mathrm{t} / \mathrm{bbl})$ for each process step and for both tools. With the API method, the result was $0.54 \mathrm{tCO}_{2 \mathrm{e}} / \mathrm{bbl}$, higher than that predicted by the US with 0.51 $\mathrm{tCO}_{2 \mathrm{e}} / \mathrm{bbl}$. This value is similar if compared to the natural-source and Coal SNG plant $\mathrm{CO}_{2}$-EOR, and to the average domestic U.S. oil (Hussaint et al., 2013) lifecycle emissions factor of $0.50 \pm 0.02 \mathrm{t} / \mathrm{bbl}$ (Figure 6). However, it is lower than the result of the life cycle $\mathrm{EF}$ of Mexican crude oil of $0.55 \mathrm{tCO}_{2 \mathrm{e}} / \mathrm{bbl}$ reported by Mangmeechai (2009), which includes extraction, transportation, and refining emissions. The slight differences between tools are in the upstream emissions. These minor differences between API and US are due to the relationships between the assumptions and boundary issues that have an impact on the magnitude of the calculated life-cycle emissions. In this regard, the same study can give differing results in likelihood because a different boundary system exists in the process, as well as the material inventory in Umberto at upstream emissions with respect to API. This comparison helps to demonstrate that the choice of boundary, assumptions or accounting methods can have an impact on the end results of the LCA studies.

\section{INSERT TABLE 7 AND FIGURE 6 HERE}

\subsection{Other environmental impacts from the Brillante $\mathrm{CO}_{2}$-EOR project}

Table 8 shows the resulting life cycle assessment impact (LCIA) obtained with US for the whole project.

Fossil depletion registers a value of $4,109 \mathrm{~kg}$ of oil in the six subsystems. This value represents an equivalent to $0.172 \mathrm{TJ}$ used energy and $5.18 \mathrm{~m}^{3}$ for water depletion along the value chain. Next to the climate change category, human toxicity is the most important environmental impact category with a value of $44.5 \mathrm{~kg} \mathrm{1,4-DCB}$.

\section{INSERT TABLE 8 HERE}

\subsection{Assessment of the energy balance}

To analyse the storage factor of the Brillante $\mathrm{CO}_{2}$-EOR project, Arteaga-Cardona et al. (2015) study results were used. Their estimations were based on $\mathrm{CO}_{2}$ miscible flood predictive models. $\mathrm{CO}_{2}$ injection is expected to further decrease the sharp decline in 
pressure of the Brillante field, and increase oil production up to 5,900 bpd by injecting $15 \times 10^{6}$ cubit feed per day $\left(834 \mathrm{tCO}_{2} / \mathrm{d}\right)$, for a total of $22 \times 10^{9}$ standard cubic feet (Bscf) throughout the nine-year duration of the project. A cumulative oil production of 5.2 million bbl is expected, with the added benefit of sequestering approximately $50 \%$ or $1.3 \mathrm{Mt}$ of the $\mathrm{CO}_{2}$ injected to the field. This storage factor does not take into account direct and indirect emissions by the EOR operation, so this must be recalculated adjusting the retention rates, which tend to be lower than $50 \%$. Additionally, this result is 10 to $20 \%$ higher to that reported by Leach et al. (2011), who gave a value of approximately 30-40\% of the $\mathrm{CO}_{2}$ injected during a single injection, which typically remains trapped in the reservoir. It is important to point out that retention rates within a $\mathrm{CO}_{2}$-EOR operation vary depending on the reservoir properties, injection strategy and oil gravity along with other factors. Therefore, according Arteaga-Cardona et al. (2015), considering GHG emissions in the EOR operation, $\mathrm{CO}_{2}$-EOR Brillante project has storage factors of $203.9 \mathrm{kgCO}_{2} /$ barrel of oil produced, this being within the range of that reported in other cases of EOR operations of 170 to $300 \mathrm{~kg} \mathrm{CO} /$ barrel of oil (Stewart and Haszeldine, 2014). $\mathrm{CO}_{2}$ recovered from the reservoir will be re-injected and not vented, meaning that 7.07 barrels oil extracted per net metric ton $\mathrm{CO}_{2}$ are injected. This value is of interest and is in contrast to that reported by McCoy and Rubin (2008) and Hussain et al. (2013), with values of $4.6 \mathrm{bbl} / \mathrm{tCO}_{2}$ or compared to the average US figure of $3.8 \mathrm{bbl} / \mathrm{tCO}_{2}$ (Stewart and Haszeldine, 2014). NTEL also (2010) reported $4.35 \mathrm{bbl} / \mathrm{tCO}_{2}$ for tertiary injection EOR best practices based on a water alternating gas (WAG). Therefore, an increment in the crude recovery ratio reduces the amount of $\mathrm{CO}_{2}$ required and the corresponding $\mathrm{CO}_{2}$ storage (Cooney et al., 2015). As it has been indicated by Dai et al. (2014b), these different results suggest that $\mathrm{CO}_{2}$ injection/storage and oil/gas recovery rates are the major intrinsic reservoir parameters. For instance, in the case of the Artesa $\mathrm{CO}_{2}$-EOR project in Mexico, LeonGarcia et al. (2015) found a value of $2.2 \mathrm{bbl} / \mathrm{tCO}_{2}$. These recovery rates are different to those of the Brillante project, despite the Artesa project being located in the same region in Tabasco State, but with different geology.

With respect to the effectiveness of $\mathrm{CO}_{2}$-EOR projects to store net $\mathrm{CO}_{2}$, if the reasoning of Faltison and Gunter (2011) regarding world oil production being controlled by demand is considered, implementing $\mathrm{CO}_{2}$-EOR projects will not result in incremental aggregate oil consumption emissions. Thus, this approach is made under the assumption that if oil were not produced by $\mathrm{CO}_{2}$-EOR, then another source would have to be developed to fill the gap. The study states that only relevant fugitive emissions that are directly associated with the $\mathrm{CO}_{2}$-EOR project should be included in the life cycle assessment of the project. Consequently, product refining and combustion in the system boundary of the analysis should be discounted.

From this point of view, if only subsystems III (Ammonia plant) and IV (EOR operation in CPOA) are considered, for every barrel of petroleum recovered, subtracting the geological sequestration and the displacement for ammonia production as avoided burden would, on average, produce a value of $0.03 \mathrm{tCO}_{2 \mathrm{e}} / \mathrm{bbl}$.

The Brillante $\mathrm{CO}_{2}$-EOR project case comes with additional useful energy (Faltison and Gunter, 2011) due to the 'additional oil', not being used. Table 9 shows that with the energy provided by the $834 \mathrm{tCO}_{2} / \mathrm{d}$ from the ammonia plant, equivalent to 3,699 $\mathrm{TJ}$, the Brillante $\mathrm{CO}_{2}$-EOR project would provide primary energy additional to 33,189 TJ during EOR operation. This means that with only $11.1 \%$ of energy (i.e. $834 \mathrm{tCO}_{2} / \mathrm{d}$ ), the net energy generated would be $28,488 \mathrm{TJ}$, along with economic profits. Without the project, 
there would continue to be a loss of energy by continual venting of $\mathrm{CO}_{2}$ into the atmosphere, equivalent to $16,751 \mathrm{TJ}$, without taking economic profits into account. Hence, when compared with the average US figure of $3.8 \mathrm{bbl} / \mathrm{tCO}_{2}$ of energy generated, which is the equivalent of $0.024 \mathrm{TJ} / \mathrm{tCO}$, the Brillante $\mathrm{CO}_{2}$-EOR project would provide $53.3 \%$ of additional energy.

\section{INSERT TABLE 9 HERE}

Table 10 shows the main key indicators of the Brillante $\mathrm{CO}_{2}$-EOR project, which included the upstream and downstream emissions.

\section{INSERT TABLE 10 HERE}

Due to the fact that the current storage factor is very low because of their immiscibility characteristics and given that the results were obtained based on a $\mathrm{CO}_{2}$ miscible predictive model and not by Huff \& Puff tests (pilot tests in the field), verification of the operational parameters and $\mathrm{CO}_{2}$ storage factor with an immiscible model would be worthwhile. It would be important to consider incorporating a separation and re-injection system for the $\mathrm{CO}_{2}\left(\mathrm{CO}_{2}\right.$ recycle plant), which is mixed with the oil in order to make a "closed loop" system. This approach $\mathrm{CO}_{2}$-EOR+CCS would allow the $\mathrm{CO}_{2}$ storage factor ratio to be increased whilst decreasing crude recovery (Cooney et al., 2015).

\section{Sensitivity analysis}

A sensitivity analysis (SA) was undertaken on three important assumptions used in the study. The scenarios were as follows:

SA1: Use of specific emissions values for the Brillante EOR field operations.

SA2: Changing values of geological sequestration with the change of emissions in EOR field operations.

SA3: Potential $\mathrm{CO}_{2}$ capture flue gas from primary reformer of ammonia plant, using an old $\mathrm{CO}_{2}$ capture unit (MEA solutions) from ammonia plant I.

The emissions from EOR field operation are important as they have a significant impact on the GW impact results in the study. Given the facilities (Table 2) and production at the Brillante field (Arteaga-Cardona et al., 2015), this study estimated, using equations 1 and 2, an emission of $0.015 \mathrm{tCO}_{2 \mathrm{e}} / \mathrm{bbl}$ for EOR field operations. This sensitivity recognizes the variations in the emissions of EOR field operations from 0.060 (see Table 3) up to 0.015 $\mathrm{tCO}_{2 \mathrm{e}} / \mathrm{bbl}$. The sensitivity is based on an emitted value that is $75 \%$ lower than the Hussaint et al. (2013) study. However, it is important to comment that this study does not take into account GHG emissions from the operation of the $\mathrm{CO}_{2}$ recycling plant; therefore, the value used for EOR operations in Brillante must exceed $0.015 \mathrm{tCO}_{2 \mathrm{e}} / \mathrm{bbl}$.

When post-combustion $\mathrm{CO}_{2}$ capture through process simulations (PS) was done assuming a new emissions value for the EOR operation, the geological sequestration changed from $-0.203 \mathrm{tCO}_{2 \mathrm{e}} / \mathrm{bbl}$ (base case) to $-0.248 \mathrm{tCO}_{2 \mathrm{e}} / \mathrm{bbl}$ or $18.1 \%$ more of $\mathrm{CO}_{2}$ storage.

Results show that 372,426 tons/year of $\mathrm{CO}_{2}$ may be captured from flue gas of the primary reformer of an ammonia plant of 480,000 tons/y of capacity (Morales-Mora et al., 
2016). The emissions of the ammonia plant are $0.26 \mathrm{tCO}_{2 \mathrm{e}} / \mathrm{bbl}$. This study carried out an LCA for this new scenario in the ammonia plant; the result of $\mathrm{CO}_{2}$ capture shows a new value of $0.105 \mathrm{tCO}_{2 \mathrm{e}} / \mathrm{bbl}$, i.e. a $\mathrm{CO}_{2}$ emissions reduction of $40 \%$. The results of these scenarios were incorporated (Table 7) to visualise the variation of new GHG emission results per barrel extracted.

Figure 7 shows the change in the GW results depending on the assumptions made for the oil field operation, geological sequestration and $\mathrm{CO}_{2}$ capture from flue gas from the ammonia plant, and their comparison with the base case (US) and $\mathrm{NGCC} \mathrm{CO}_{2}$-EOR.

For scenario one (S1), the results show that the GW impacts have 7\% lower emissions per barrel of oil extracted with a new value of oil field operation with respect to the base case (Ammonia plant- $\mathrm{CO}_{2}$-EOR, see value US of table 5). However, the emissions are still $34 \%$ higher with respect to the $\mathrm{NGCC} \mathrm{CO}_{2}$-EOR case (Hussaint et al., 2013). The results of the sensitivity analysis for $\mathrm{S} 2$ show an appropriate response to the induced modifications of geological sequestration which showed the same behaviour, with a reduction of the total emissions per barrel extracted from the $17.6 \%$ for base case, but still superior at $20 \%$ to the NGCC $\mathrm{CO}_{2}$-EOR case. The sensitivity analysis for $\mathrm{S} 3$ shows a positive impact as a consequence of the potential capture of $1,000 \mathrm{t} / \mathrm{d}$ of $\mathrm{CO}_{2}$ gases from combustion of the primary reformer of the ammonia plant. This variable results from implementing postcombustion $\mathrm{CO}_{2}$ capture from the ammonia plant. It can be observed that with a combination of the three scenarios, the $\mathrm{CO}_{2}$ per barrel produces a reduction in the total $\mathrm{CO}_{2}$ emissions on the EOR system of the order of $49 \%$ in comparison with the base case and $25.7 \%$ with respect to $\mathrm{NGCC} \mathrm{CO}_{2}$-EOR case. Consequently, post-combustion $\mathrm{CO}_{2}$ capture in the ammonia plant may represent a relevant factor to consider for reducing $\mathrm{CO}_{2 \mathrm{e}}$ emissions and increase the energy efficiency of a CCUS system.

\section{INSERT FIGURE 7 HERE}

\section{Conclusions and recommendations}

Both LCA and API tools produced accurate estimations of the GHG emission in the EOR system for the oil and gas industries. The differences between both tools were in the upstream emissions (subsystem I and II), with a ratio of 0.42 to 3.5, which are not relevant since these subsystems contribute only eight per cent of the total emissions. At the downstream emissions (Subsystem III to VI), no differences were found in the results for both methodologies with a ratio close to 1 . This lack of difference between the US and API is owed to the adjustment to the conditions of the EF of the oil and gas sectors for Mexico Ecoinven in Umberto materials and processes.

Both tools appear to be clear, fast and comprehensive for the purpose of LCA-CCS studies, which can be used within the particularities of the oil and gas industries in Mexico. The API used to estimate the GHG emission in the oil and gas sector projects was validated and can be applied through calculations performed 'manually' in a spreadsheet by practitioners and researchers intending to analyse the GHG emission of CCS. This comparison allows the estimation and acknowledgement of GHG emissions in the whole chain of value of the project; as well as the energy demand to produce one barrel of oil through EOR. The results of the comparison between both tools prove that API made an accurate calculation of the life cycle emissions to the EOR system when US with standard databases are not available. Overall, the use of $\mathrm{CO}_{2}$ process stream in the petrochemical 
sector for the EOR system in Mexico registered a lower environmental footprint, but slightly higher in comparison with alternative $\mathrm{CO}_{2}$ sources for $\mathrm{CO}_{2}-\mathrm{EOR}$, to coal or $\mathrm{NG}$ combustion (Pulverized coal-fired PP, Integrated gasification CC, NGCC). The use of different boundary systems, databases, allocation of by-products, functional units (1 MWh or kWh of Electricity) and technologies for $\mathrm{CO}_{2}$ capture in the LCA-CCS study, make it difficult to make comparisons when assessing the environmental performance from power plants versus process stream of the oil and gas sectors.

The energy balance is positive because, with $\mathrm{CO}_{2}$-EOR, LCA from the oil and gas industries has so far received little attention, in spite of being an important tool to address and compare different technological options. From the standpoint of energy efficiency, the Brillante $\mathrm{CO}_{2}$-EOR project provides $46 \%$ of additional primary energy, than average, of $\mathrm{CO}_{2}$-EOR in the U.S. (3.8 bbl/tCO 2$)$. The total $\mathrm{CO}_{2}$ storage during the EOR operation could achieve 1.3 million tons. In spite of the limited availability of LCA literature on process streams from petrochemical or refining processes to CCS or EOR, these technologies will generate the lowest relative increase in the environmental impact categories.

Based on the results of this study, the use of manual calculations for studies on LCACCUS is recommended, where quick adjustments or updates at the EF regional or local level can be made at any time in the worksheets, in accordance with operative guidelines determined by the oil and gas companies in contrast to the Ecoinvent database.

\section{Supporting Information}

The Supporting Information file accompanying this paper includes a Table SI-1with the steps for calculated $\mathrm{CO}_{2 \mathrm{e}}$ by API method as well as material and energy flow network of Brillante $\mathrm{CO}_{2}$-EOR project.

\section{Acknowledgments}

The authors would like to thank the Gregory Conney and Timothy J. Skone of National Energy Technology Laboratory-LCA U.S. Department of Energy for their comments, which helped to clarify and improve the presentation of the results of this work and to Maria del C. Avalos Islas for her invaluable support and contributions to this study. Moreover, the authors would like to acknowledge Mr. Emiliano Leiva and Dr. Anya Leiva for the final writing of the text.

This research did not receive any specific grant from funding agencies in the public, commercial, or not-for-profit sectors.

\section{References}

API, 2009. Compendium of Greenhouse Gas Emissions Estimation Methodologies for the Oil and Natural Gas Industry. Version 3.0, August 2009. American Petroleum Institute, Washington D.C.

API (American Petroleum Institute), 2011. API SPEC 5L: Specification for Line Pipe. American Petroleum Institute. 
Arteaga Cardona M., F. Rodríguez de la Garza, I. Báez Marín, 2015. Inyección de bióxido de carbono en el campo Brillante $\left[\mathrm{CO}_{2}\right.$ injection in the Brillante field]. Ingeniería Petrolera, Vol. 55 No. 10, Octubre. ISSN 0185-3899, México.

Armstrong K. and P. Styring, 2015. Assessing the potential of utilization and storage strategies for post-combustion $\mathrm{CO}_{2}$ emissions reductions. Front. Energy Res. Vo. 3. Art. 8.

ARI and Melzer Consulting, 2010. Optimization of $\mathrm{CO}_{2}$ storage in $\mathrm{CO}_{2}$-enhanced oil recovery projects, report for the UK Department of Energy and Climate Change. Available at: www.adv-res.com/pdf/1006-optimization-of-co2-storage-in-co2enhanced-oil-re.pdf (accessed 10.10.15).

Bandyopadhyay A. 2011. Amine versus ammonia absorption of $\mathrm{CO}_{2}$ as a measure of reducing GHG emission: a critical analysis. Clean Techn. Environ. Policy 13, 269-294.

Bandza A. J.and S. P. Vajjhala, 2014. Modeling the Transition from Enhanced Oil Recovery to Geologic Carbon Sequestration. Manage. Decis. Econ. 35: 20-35.

Brandão M., \& A. Levasseur, M. U. F. Kirschbaum, B. P. Weidema, A. L. Cowie, S. V. Jørgensen, M. Z. Hauschild, D. W. Pennington and K. Chomkhamsri, 2013. Key issues and options in accounting for carbon sequestration and temporary storage in life cycle assessment and carbon footprinting. Int J Life Cycle Assess, 18:230-240

Corsten M., Andrea Ramírez, Li Shen, Joris Koornneef, André Faaij, 2013. Environmental impact assessment of CCS chains - Lessons learned and limitations from LCA literature. Int. J. Greenh. Gas Control. Volume 13, Pages 59-71.

Cooney G., J. Littlefield,J. Marriott and T. J. Skone, 2015. Evaluating the Climate Benefits of $\mathrm{CO}_{2}$ Enhanced Oil Recovery Using Life Cycle Analysis. Environ. Sci. Technol. 49, 7491-7500.

Cuellar-Franca R.M. and A. Azapagic, 2015. Carbon capture, storage and utilisation technologies: A critical analysis and comparison of their life cycle environmental impacts. J. $\mathrm{CO}_{2}$ Util. 9, 82-102.

Dai, Z., Middleton, R., Viswanathan, H., Fessenden-Rahn, J., Bauman, J., Pawar, R., Lee, S.-Y. and McPherson, B., 2014a. An integrated framework for optimizing $\mathrm{CO}_{2}$ sequestration and enhanced oil recovery. Environ. Sci. Technol. Lett. 1 (1), 49-54.

Dai, Z., Viswanathan, H., Fessenden-Rahn, J., Middleton, R., Pan, F., Jia, W., Lee, S.-Y., McPherson, B., Ampomah, W. and Grigg, R. 2014b. Uncertainty quantification for $\mathrm{CO}_{2}$ sequestration and enhanced oil recovery. Energy Procedia, 63 (0), 7685-7693.

Dávila M., O. Jiménez, R. Castro, V. Arévalo, J. Stanley and L.M. Cabrera, 2010. A preliminary selection of regions in Mexico with potential for geological carbon storage. Int. J. Phys. Sci. Vol. 5(5), pp. 408-414.

EPRI (Electric Power Research Institute), 2013. Update on Utilization or Storage of $\mathrm{CO}_{2}$ through Chemical, Biological, or Mineral Conversion. Report No. 3002001006, Electric Power Research Institute, Palo Alto, CA. Available at: www.epri.com/abstracts/Pages/ProductAbstract.aspx?ProductId=000000003002001006 (accessed 05.17.15)

Faltison, J. and Gunter, B., 2011. Net $\mathrm{CO}_{2}$ Stored in North American EOR Projects. Society of Petroleum Engineers, Canadian Unconventional Resources and International Petroleum Conference. Calgary: SPE.

Goedkoop M, Heijungs R, Huijbregts M, De Schryver A, Struijs J, VanZelm R, 2009. ReCiPe 2008. VROM Ruimte en Milieu, Ministerie van Volkshuisvesting, Ruimtelijke Ordening en Milieubeheer. Available at: www.lcia-recipe.net (accessed 12.11.15). 
Global CCS Institute, 2015. The Global Status of CCS: 2015. Summary Report. Available at: www.globalccsinstitute.com/publications/global-status-ccs-2015 (accessed 10.10.15).

Haas MJGde, van Dijk TA., 2010. Inventarisatie klimaatvriendelijke kunstmest. Wageningen: Nutriënten Management Instituut NMI. Available at: www.rvo.nl/sites/default/files/bijlagen/Inventarisatie\%20klimaatvriendelijke\%20kunst mest\%20-\%20Rapport\%20-\%20november\%202010.pdf (accessed 08. 11.15)

Hertwich, E., Martin Aaberg, Bhawna Singh and Anders H. Strømman, 2008. Life-cycle Assessment of Carbon Dioxide Capture for Enhanced Oil Recovery. Chinese J. Chem. Eng., 16 (3) 343-353

Hussain D., David A. Dzombak, Paulina Jaramillo, Gregory V. Lowry, 2013. Comparative lifecycle inventory (LCI) of greenhouse gas (GHG) emissions of enhanced oil recovery (EOR) methods using different CO2 sources. Int. J. Greenh. Gas Control. 16, 129-144.

IEA (International Energy Agency), 2015. Combining EOR with $\mathrm{CO}_{2}$ storage (EOR+) for profit. Available at: www.iea.org/publications/insights/insightpublications/CO2EOR_3Nov2015.pdf (accessed 05.11.15).

IEA and UNIDO (International Energy Agency- United Nations Industrial Development Organization), 2011. Technology Roadmap Carbon Capture and Storage in Industrial Applications. Available

at: www.iea.org/publications/freepublications/publication/ccs_industry.pdf （accessed 13.06.16).

International Organization for Standardization, 2006a. ISO-14040. Environmental Management Standard- Life Cycle Assessment, Principles and Framework. International Organization for Standardization. Switzerland.

International Organization for Standardization, ISO, 2006b. ISO 14044. Environmental Management - Life Cycle Assessment - Requirements and Guidelines. International Organization for Standardization. Switzerland.

IPCC (Intergovernmental Panel Climate Change), 2007. Climate Change 2007. The Physical Science Basis; Intergovernmental Panel for Climate Change, Fourth Assessment Report. Cambridge University Press, New York. Available at: www.ipcc.ch/ipccreports/ar4-wg1.htm. (Accessed 20.11.15).

Jaramillo, P. W. Michael Griffin and S. Mc Coy, 2009. Life Cycle Inventory of $\mathrm{CO}_{2}$ in an Enhanced Oil Recovery System. Environ. Sci. Technol. 43, 8027-8032.

Lacy R., C. Serralde, M. Climent and M. Vaca, 2012. Initial assessment of the potential for future CCUS with EOR projects in Mexico using $\mathrm{CO}_{2}$ captured from fossil fuel industrial plants. Int. J. Greenh. Gas Control. 19, 212-219.

Lacy R., M. Molina, M. Vaca, C. Serralde, G. Hernandez, G. Rios, E. Guzman, R. Hernandez, R. Perez, 2015. Life-cycle GHG assessment of carbon capture, use and geological storage (CCUS) for linked primary energy and electricity production. Int. J. Greenh. Gas Control. 42, 165-174

León García A, F. Samaniego Verduzco, S. García Rodríguez, F. García Hernández, H. Rodríguez García, 2015. Inyección de $\mathrm{CO}_{2}$ en condiciones miscibles en el yacimiento naturalmente fracturado Artesa $\left[\mathrm{CO}_{2}\right.$ injection in miscible condition in the Artesa naturally fractured oil reservoir]. Ingeniería Petrolera. Vol. 55 No. 10, octubre · ISSN 0185-3899, México. 
Leach, A.; Mason, C. F.; Veld, K. v. t, 2011. Co-optimization of enhanced oil recovery and carbon sequestration. Resour. Energy Econ. 33 (4), 893-912.

Leung, D. Y. C.; Caramanna, G.; Maroto-Valer, M. M. An overview of current status of carbon dioxide capture and storage technologies. Renew. Sustain. Energy Rev. 2014, $39,426-443$.

Levasseur A., 2015. Climate Change, in: LCA Compendium - The Complete World of Life Cycle Assessment. Michael Z. Hauschild and Mark A. J. Huijbregts (Eds.) Springer Science+Business Media Dordrecht, pp. 39-50.

Luis, P. 2015. Use of monoethanolamine (MEA) for $\mathrm{CO}_{2}$ capture in a global scenario: Consequences and alternatives. Desalination. Volume 380, Pages 93-99.

Marx, J., Schreiber, A., Zapp, P., Haines, M., Hake, J. Fr. and Gale, 2011. Environmental evaluation of CCS using Life Cycle Assessment - a synthesis report. Energy Procedia 4, $2448-2456$

Mangmeechai, A., 2009. Life cycle greenhouse gas emissions, consumptive water use and levelised costs of unconventional oil in North America. Pittsburgh: Carnegie Mellon University.

Makhlouf A, Tayeb Serradj, Hamza Cheniti, 2015. Life cycle impact assessment of ammonia production in Algeria: A comparison with previous studies. Environ. Impact Assess. Rev.50, 35-41

Manuilova, A., Koiwanit, J., Piewkhaow, L., Wilson, M., Chan, C.W. and Tontiwachwuthikul, P., 2014. Life Cycle Assessment of Post-Combustion $\mathrm{CO}_{2}$ Capture and $\mathrm{CO}_{2}$-Enhanced Oil Recovery based on the Boundary Dam Integrated Carbon Capture and Storage Demonstration Project in Saskatchewan. Energy Procedia 63, 7398 $-7407$

Morales-Mora M.A., Pretelín Vergara, C., Leiva, M.A., Martínez Delgadillo, S.A. and Rosa-Domínguez, E.R., 2016. Life cycle assessment of carbon capture and utilization from ammonia process in Mexico. J. Environ. Manage.183, 998-1008.

McCoy, S.T., Rubin, E.S., 2008. An engineering-economic model of pipeline transport of $\mathrm{CO}_{2}$ with application to carbon capture and storage. Int. J. Greenh. Gas Control. 2, 219-229.

National Institute of Ecology and Climate Change, 2014. Emission factors for the different types of fossil fuels and alternatives consumed in Mexico [Factores de emisión para los diferentes tipos de combustibles fósiles y alternativos que se consumen en México]. Available

at: www.inecc.gob.mx/descargas/cclimatico/2014_inf_fin_tipos_comb_fosiles.pdf (accessed 12.10.15).

National Hydrocarbons Commission, 2016. Statistics. Hydrocarbon Reserves. Available at: www.cnh.gob.mx/56000.aspx (Accessed 03.02.16).

Nagashima, S.; Miyagawa, T.; Matsumoto, M.; Suzuki, S.; Komaki, H.; Takagi, M.; Murai, S., 2011. Life cycle assessment performed on a CCS model case in Japan and evaluation of improvement facilitated by heat integration. Energy Procedia 4, 24572464.

NTEL (National Energy Technology Laboratory), 2010. An Assessment of Gate-to-Gate Environmental Life Cycle Performance of Water-Alternating- Gas $\mathrm{CO}_{2}$-Enhanced Oil Recovery in the Permian Basin; DOE/NETL-2010/1433; National Energy Technology Laboratory: Pittsburgh, PA, 2010; 

R_LCA_0930 10.pdf. (accessed 10.06.16)

NTEL, 2013a. Cradle-to-Gate Life Cycle Analysis Model for Alternative Sources of Carbon Dioxide. 50 p. Available at: www.netl.doe.gov/File\%20Library/Research/Energy\%20Analysis/Life\%20Cycle\%20A nalysis/CtG-LCA-of-Alternative-CO2.pdf (accessed 21.02.16).

NETL, 2013b. Gate-to-Grave Life Cycle Analysis Model of Saline Aquifer Sequestration of Carbon Dioxide. Available www.netl.doe.gov/File\%20Library/Research/Energy\%20Analysis/ Life\%20Cycle\%20Analysis/GtG-LCA-of-Saline-Aquifer-Sequestration.pdf. (accessed 15.03.16).

NTEL, 2015. Commercial technologies. Available at: www.netl.doe.gov/research/Coal/energy-systems/gasification/gasifipedia/fertilizercommercial-technologies (accessed 15.11.15).

Overcash M., Yong Li, Evan Griffing and Gareth Rice, 2007. A life cycle inventory of carbon dioxide as a solvent and additive for industry and in products. J. Chem. Technol. Biotechnol. 82:1023-1038.

Petrakopoulou F. and G. Tsatsaronis, 2014. Can Carbon Dioxide Capture and Storage from Power Plants Reduce the Environmental Impact of Electricity Generation?. Energy Fuels. 28 (8), 5327-5338.

PEMEX (Petróleos Mexicanos), 2014. Sustainability Report 2014. Available at: www.pemex.com/en/responsibility/sustainable/reports/Paginas/default.aspx (accessed 02.09.15).

PEMEX, 2015. Statistical. Institutional database. 2015 Available at: www.ebdi.pemex.com/bdi/bdiController.do?action=cuadro\&cvecua=ECRURA (accessed 17.09.15).

Rochelle G., E. Chen, S. Freeman, D. Van Wagener, Q. Xu, A., 2011. Voice, Aqueous piperazine as the new standard for $\mathrm{CO}_{2}$ capture technology, Chem. Eng. J. 171, 725733.

SENER (Energy Secretariat), 2014. Mexico CCUS technological roadmap [Mapa de Ruta Tecnológica de CCUS en Mexico]. Mexico, DF. 31 p. Available at: www.gob.mx/sener/documentos/mapa-de-ruta-tecnologica-ccus (accessed 08.12.15).

SEMARNAT-INECC ((Secretariat of Environment and Natural Resources-National Institute of Ecology and Climate Change), 2016. Mexico's Climate Change MidCentury Strategy. Ministry of Environment and Natural Resources (SEMARNAT) and National Institute of Ecology and Climate Change (INECC), Mexico City, Mexico. Available at: unfccc.int/files/focus/longterm_strategies/application/pdf/mexico_mcs_final_cop22nov1 6_red.pdf (accessed 22.11.2016).

Spath, P., Mann, M., 2004. Biomass Power and Conventional Fossil Systems with and Without $\mathrm{CO}_{2}$ Sequestration-Comparing the Energy Balance, Greenhouse Gas Emissions and Economics. National Renewable Energy Laboratory, Colorado, United States of America.

Stéphenne K., 2014. Start-Up of World's First Commercial Post-Combustion Coal Fired CCS Project: Contribution of Shell Cansolv to SaskPower Boundary Dam ICCS Project. Energy Procedia 63, 6106-6110 
Stewart R Jamie and S. Haszeldine, 2014. Carbon Accounting for Carbon Dioxide Enhanced Oil Recovery. Scottish Carbon Capture \& Storage, UK. Available at: www.sccs.org.uk. (Accessed 12.02.16).

Strazza C., Adriana Del Borghi and Michela Gallo, 2013. Development of Specific Rules for the Application of Life Cycle Assessment to Carbon Capture and Storage. Energies, $6,1250-1265$.

USEPA (United States Environmental Protection Agency), 2015. Inventory of U.S. Greenhouse Gas Emissions and Sinks: 1990-2013. EPA 430-R-15-004

Van der Zwaan, B. and K. Smekens, 2010. $\mathrm{CO}_{2}$ Capture and Storage with Leakage in an Energy-Climate Model. Environ. Model. Assess. 14 (2): p. 135-148.

Venkatesh, A.; Jaramillo, P.; Griffin, W. M.; Matthews, H. S., 2011. Uncertainty analysis of life cycle greenhouse gas emissions from petroleum-based fuels and impacts on low carbon fuel policies. Environ. Sci. Technol, 45, 125-131

Von der Assen N, P. Voll M. Petersb and A. Bardow, 2014. Life cycle assessment of $\mathrm{CO}_{2}$ capture and utilization: a tutorial review. Chem. Soc. Rev. 43, 7982-7994.

Volkart K, Ch. Bauer, C. Boulet, 2013. Life cycle assessment of carbon capture and storage in power generation and industry in Europe. Int. J. Greenh. Gas Control. 16, 91-106

Wang, M., M. Wu, H. Huo, and J. Liu, 2008, "Well-to-Wheels Energy Use and Greenhouse Gas Emissions of Brazilian Sugarcane Ethanol Production Simulated by Using the GREET Model,” Int. Sugar J., Vol. 110, No. 1317: 527-545.

Williams G. and Al-Ansari F., 2007. IFA Benchmarking of Global Energy Efficiency in Ammonia Production. Workshop on Energy Efficiency and $\mathrm{CO}_{2}$ Reduction Prospects in Ammonia Production, In. Ho Chi Minh City, Vietnam: IFA Technical Committee Meeting; [12-14 March].

Xiao L.S., R. Wang, P.-Ch. Chiang, S.Y. Pan, Q.-H. Guo, E.E Chang, 2014. Comparative Life Cycle Assessment (LCA) of Accelerated Carbonation Processes Using Steelmaking Slag for $\mathrm{CO}_{2}$ Fixation. Aerosol and Air Quality Research, 14: 892-904.

Zapp, P., Schrieber, A., Marx, J., Haines, M., Hake, J., Gale, J., 2012. Overall environmental impacts of CCS technologies- a life cycle approach. Int. J. Greenhouse Gas Contr. 8, 12-21. 
Table 1. Capacity of key facilities in Brillante oil field

\begin{tabular}{cccc}
\hline Item & No & $\begin{array}{c}\text { Nominal } \\
\text { Bbl/d }\end{array}$ & $\begin{array}{c}\text { Nominal } \\
\text { MMSCF/d }\end{array}$ \\
\hline Operation well & 12 & & 16 \\
Horizontal separator & 1 & 55,000 & 20 \\
Slag catcher & 1 & 3.5 & 2 \\
Storage tank & 8 & 500 & \\
Gas compressor & 1 & & \\
Pump & 1 & 10,000 & \\
Flare & 1 & ----- & \\
Tanks & 8 & $4000 \mathrm{bbl}$ & \\
\hline
\end{tabular}

Table 2. Description of the $\mathrm{CO}_{2}$-EOR subsystems

(Adapted from Makhlouf et al., 2015)

\begin{tabular}{|c|c|c|c|c|}
\hline \multicolumn{2}{|r|}{ Subsystems } & Operation units studied & \multirow[t]{2}{*}{ Facility } & \multirow{2}{*}{$\begin{array}{c}\begin{array}{l}\text { Functions } \\
\text { performed }\end{array} \\
\begin{array}{c}\text { Natural gas } \\
\text { extraction }\end{array}\end{array}$} \\
\hline $\mathrm{I}$ & Extraction NG & $\begin{array}{l}\text { Extraction and pumping of associated natural } \\
\text { gas to Atasta station boosting center (SBC) and } \\
\text { then to Nuevo PEMEX Gas Processing } \\
\text { Complex (NPGPC). Include separation of } \\
\text { natural gas; gas compression; gas NG transport; } \\
\text { recompression. }\end{array}$ & & \\
\hline II & NG processing & $\begin{array}{l}\text { Cooling dehydration; separation of gas and } \\
\text { liquid hydrocarbons; } \\
\text { recompression }\end{array}$ & NPGPC & $\begin{array}{l}\text { Liquefaction- } \\
\text { compressions }\end{array}$ \\
\hline III & $\begin{array}{l}\text { Ammonia } \\
\text { production }\end{array}$ & 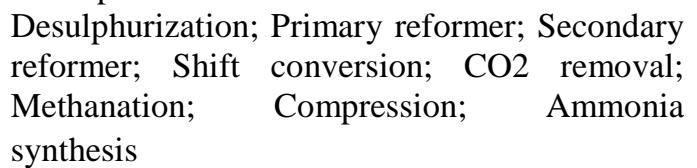 & $\mathrm{CPC}$ & $\begin{array}{l}\text { Ammonia } \\
\text { production }\end{array}$ \\
\hline IV & $\mathrm{CO}_{2}$-EOR & $\begin{array}{l}\text { Extraction and pumping of oil recovery to } \\
\text { Minatitlan Refinery }\end{array}$ & $\begin{array}{l}\text { Mature oil } \\
\text { well }\end{array}$ & Oil recovery \\
\hline $\mathrm{V}$ & Refining oil & Light, middle and heavy distillates & $\begin{array}{l}\text { Minatitlan } \\
\text { Refinery }\end{array}$ & $\begin{array}{l}\text { Gasoline, diesel } \\
\text { production }\end{array}$ \\
\hline VI & $\begin{array}{l}\text { Refinery } \\
\text { product } \\
\text { combustion }\end{array}$ & Gasoline combustion & Car & GHG emissions \\
\hline
\end{tabular}


Table 3. Sum up of key input parameters utilized in model of $\mathrm{CO}_{2}-\mathrm{EOR}$ project model (adapted from Hussain et al. 2013)

\begin{tabular}{|c|c|c|}
\hline Input parameter/project emissions & $\begin{array}{l}\text { Parameter } \\
\text { value }\end{array}$ & Reference \\
\hline $\begin{array}{l}\text { Oil production ratio/EOR process efficiency } \\
\text { (Barrels oil extracted per net metric ton } \mathrm{CO}_{2} \\
\text { injected) }\end{array}$ & $7.07 \mathrm{bbl} / \mathrm{tCO}_{2}$ & Arteaga-Cardona et al. (2015) \\
\hline Geological sequestration of $\mathrm{CO}_{2}$ during EOR & $0.20 \mathrm{tCO}_{2} / \mathrm{bbl}$ & Hussaint et al. (2015) \\
\hline Refined oil product combustion emissions & $0.44 \mathrm{t} / \mathrm{bbl}$ & INECC (2014) \\
\hline $\mathrm{CO}_{2}$ capture efficiency & $97.5 \%$ & Ammonia plant in CPC \\
\hline $\mathrm{CO}_{2}$ leakage rate & $0.01 \% /$ year & $\begin{array}{l}\text { (van der Zwaan and Smekens } \\
\text { (2010) }\end{array}$ \\
\hline Electricity use emissions (PEMEX) & $460 \mathrm{~kg} \mathrm{CO} \mathrm{CO}_{2} / \mathrm{MWh}$ & Own estimate \\
\hline $\begin{array}{l}\text { Refinery operations } \\
\left(\mathrm{tCO}_{2} / \mathrm{bbl} \text { oil refinery) }\right.\end{array}$ & 0.03 & $\begin{array}{l}\text { ARI \& Melzer Consulting, } \\
\qquad 2010\end{array}$ \\
\hline CCS capture efficiency (Brillante field) & $\begin{array}{c}50 \% \\
\text { or } 0.263 \mathrm{tCO}_{2} / \mathrm{bbl}\end{array}$ & Arteaga-Cardona et al. (2015) \\
\hline $\begin{array}{l}\mathrm{CO}_{2} \text { transport } \\
\mathrm{Gg} \mathrm{CO}_{2} / \mathrm{km} \text { of pipeline per year }\end{array}$ & $2.9602 \mathrm{E}-5$ & API,2011 \\
\hline $\begin{array}{l}\text { Crude oil transport } \\
\left(\mathrm{gCO}_{2 \mathrm{eq}} / \mathrm{bbl}\right)\end{array}$ & $6.49 \mathrm{E}-5$ & Own estimate \\
\hline $\begin{array}{l}\text { EOR field operations } \\
\left(\mathrm{CO}_{2 \mathrm{e}} / \mathrm{bbl}\right)\end{array}$ & 0.06 & Hussaint et al. (2013) \\
\hline $\begin{array}{l}\text { Ammonia plant } \\
\text { Feedstock gas/combustion }\left(\mathrm{tCO}_{2 \mathrm{e}} / \mathrm{bbl}\right)\end{array}$ & 0.260 & Own estimate \\
\hline
\end{tabular}


Table 4. Method of allocation on the basis of the natural gas use as raw material

\begin{tabular}{ccccccc}
\hline Function & Inputs & Used & Unit & Quantity & $\begin{array}{c}\text { Allocation } \\
\text { factor (\%) }\end{array}$ & Output \\
\hline $\begin{array}{c}\text { Ammonia } \\
\text { plant }\end{array}$ & $\mathrm{NG}$ & $\begin{array}{c}\text { Process gas } \\
\left(\mathrm{NH}_{3}+\mathrm{CO}_{2}\right)\end{array}$ & $\mathrm{NM}^{3}$ & 749 & 55.2 & $\mathrm{NH}_{3}+\mathrm{CO}_{2}$ \\
Fuel & $\mathrm{NM}^{3}$ & 606 & 44.7 & Flue gas \\
\hline
\end{tabular}


Table 5. Comparisons of the estimating GHG emissions by subsystem and stages with US and API methods $\left(\mathrm{tCO} \mathrm{e}_{2} / \mathrm{bbl}\right)$

\begin{tabular}{|c|c|c|c|c|c|c|c|c|}
\hline \multirow[b]{3}{*}{ Subsystem } & \multirow[b]{3}{*}{ Stage } & \multirow[b]{3}{*}{ Process } & \multicolumn{6}{|c|}{$\begin{array}{c}\text { Tools } \\
\text { GW }\left(\mathbf{t C O}_{2 \mathrm{e}} / \mathbf{b b l}\right)\end{array}$} \\
\hline & & & \multicolumn{2}{|r|}{$\mathbf{U S}$} & \multicolumn{3}{|c|}{ API } & \multirow[b]{2}{*}{$\begin{array}{c}\text { Emissions } \\
\text { for } \\
\text { subsystem }\end{array}$} \\
\hline & & & Emission & $\%$ & $\begin{array}{c}\text { Emissions } \\
\text { for } \\
\text { subsystem }\end{array}$ & Emission & $\%$ & \\
\hline \multirow{5}{*}{$\mathbf{I}$} & 1 & Oil and gas Marine NE (APC) Cantarell & 0.019 & 2.2 & \multirow{5}{*}{0.03} & 0.034 & 3.8 & \multirow{5}{*}{0.04} \\
\hline & 2 & Gas compression (APC) & 0.006 & 0.7 & & 0.002 & 0.2 & \\
\hline & 3 & Pipeline gas transport (APC to Atasta) & 0.002 & 0.2 & & 0.001 & 0.1 & \\
\hline & 4 & Gas compression (Atasta) & 0.005 & 0.5 & & 0.003 & 0.3 & \\
\hline & 5 & Pipeline gas transport (Atasta to Nuevo PEMEX) & 0.004 & 0.4 & & 0.002 & 0.2 & \\
\hline \multirow{3}{*}{ II } & 6 & NG sweetening plant (Nuevo PEMEX) & 0.015 & 1.7 & \multirow{3}{*}{0.02} & 0.035 & 4.0 & \multirow{3}{*}{0.04} \\
\hline & 7 & NG (Dry) compression & 0.005 & 0.5 & & 0.003 & 0.3 & \\
\hline & 8 & Pipeline NG transport (Nuevo PEMEX to CPC) & 0.004 & 0.5 & & 0.002 & 0.3 & \\
\hline \multirow{3}{*}{ III } & 9 & Ammonia plant (CPC) & 0.259 & 30.5 & \multirow{4}{*}{0.26} & 0.270 & 30.7 & \multirow{3}{*}{0.27} \\
\hline & 10 & $\mathrm{CO} 2$ compression (CPC to $\mathrm{CP}$ EOR Project) & 0.001 & 0.2 & & 0.001 & 0.2 & \\
\hline & 11 & Pipeline $\mathrm{CO} 2$ transport (CPC to $\mathrm{CP}$ field) & $3 \mathrm{E}-05$ & 0.0 & & $3 \mathrm{E}-05$ & 0.0 & \\
\hline \multirow{3}{*}{ IV } & 12 & Operation CO2-EOR (Brillante field) & 0.060 & 7.1 & & 0.060 & 6.8 & \multirow{3}{*}{0.06} \\
\hline & 13 & $\begin{array}{l}\text { Oil recovery pumping (CP field to Minatitlan } \\
\text { Refinery) }\end{array}$ & $2 \mathrm{E}-05$ & 0.0 & \multirow[t]{2}{*}{0.06} & $2 \mathrm{E}-05$ & 0.0 & \\
\hline & 14 & Oil recovery transport to Minatitlan Refinery & $6 \mathrm{E}-05$ & 0.0 & & $6 \mathrm{E}-05$ & 0.0 & \\
\hline $\mathbf{V}$ & 15 & Refining oil (Minatitlán Refinery) & 0.032 & 3.8 & 0.03 & 0.030 & 3.4 & 0.03 \\
\hline \multirow[t]{2}{*}{ VI } & 16 & Refinery product combustion & 0.44 & 51.6 & 0.44 & 0.44 & 49.7 & 0.44 \\
\hline & & Total emissions & 0.85 & 100.0 & 0.85 & 0.88 & 100.0 & 0.88 \\
\hline
\end{tabular}


Table 6. Comparison of energy uses with each barrel recovered $\left(\mathrm{tCO}_{2 \mathrm{e}} / \mathrm{MJ}\right)$

\begin{tabular}{ccc}
\hline Subsystem & US & API \\
\hline I & 5.60 & 6.66 \\
II & 3.73 & 6.44 \\
III & 42.14 & 43.93 \\
IV & 9.71 & 9.71 \\
V & 5.16 & 4.85 \\
Average $^{\text {a }}$ & 66 & 72 \\
\hline a: Is not considered the Subsystem VI
\end{tabular}

Table 7. Lifecycle GHG emissions and inputs/outputs for EOR (metric tons of $\mathrm{CO}_{2 \mathrm{e}}$ per barrel of oil extracted) (adapted from Hussaint et al. 2013)

\begin{tabular}{|c|c|c|}
\hline Process inputs/outputs & $\begin{array}{c}\text { Ammonia plant- } \\
\mathrm{CO}_{2} \text {-EOR } \\
(\mathrm{US})\end{array}$ & $\begin{array}{c}\text { Ammonia plant- } \\
\mathrm{CO}_{2} \text {-EOR } \\
(\mathrm{API})\end{array}$ \\
\hline Feedstock used NG (t) & 406 & 406 \\
\hline Ammonia product $(\mathrm{t})$ & 1 & 1 \\
\hline $\mathrm{CO}_{2}$ generated as byproduct $(\mathrm{t})$ & 1.4 & 1.4 \\
\hline Upstream emissions (Offshore) & 0.019 & 0.034 \\
\hline Feedstock gas/combustion (Ammonia) & 0.260 & 0.270 \\
\hline NG compression & 0.015 & 0.007 \\
\hline Pipeline NG transport & 0.009 & 0.005 \\
\hline NG Sweetening plant & 0.015 & 0.035 \\
\hline $\mathrm{CO}_{2}$ compression & 0.001 & 0.001 \\
\hline Pipeline $\mathrm{CO}_{2}$ transport & 0.00003 & 0.00003 \\
\hline Oil field operations & 0.060 & 0.060 \\
\hline Geological sequestration & -0.20 & -0.20 \\
\hline $\mathrm{CO}_{2}$ leakage (100 years) & 0.002 & 0.002 \\
\hline Crude oil transportation & 0.0001 & 0.0001 \\
\hline Refinery operations & 0.032 & 0.032 \\
\hline Oil product combustion & 0.44 & 0.44 \\
\hline Ammonia/ $\mathrm{CH}_{4}$ Displacement & -0.14 & -0.14 \\
\hline Total $\left(\mathrm{tCO}_{2 \mathrm{e}} / \mathrm{bbl}\right)$ & 0.51 & 0.54 \\
\hline Energy to produce 1 bbl (MJ) & 66 & 72 \\
\hline
\end{tabular}


Table 8. LCIA results of ReCiPe for the production of 1 barrel of $\mathrm{CO}_{2}$-EOR project

\begin{tabular}{ccc}
\hline Midpoint impact category & Unit & Result/FU \\
\hline Agricultural land occupation & $\mathrm{m}^{2} \mathrm{a}$ & 0.05 \\
Climate change & $\mathrm{t} \mathrm{CO}_{2 \mathrm{e}}$ & $8.53 \mathrm{E}-01$ \\
Fossil depletion & $\mathrm{t}$ oil & $4.11 \mathrm{E}+00$ \\
Freshwater ecotoxicity & $\mathrm{t} 1,4-\mathrm{DCB}$ & $4.60 \mathrm{E}-04$ \\
Freshwater eutrophication & $\mathrm{P}$ & $1.46 \mathrm{E}-06$ \\
Human toxicity & $\mathrm{t} 1,4-\mathrm{DCB}$ & $4.45 \mathrm{E}-02$ \\
Ionising radiation & $\mathrm{U} 235$ & $4.41 \mathrm{E}-03$ \\
Marine ecotoxicity & $\mathrm{t} 1,4-\mathrm{DCB}$ & $1.19 \mathrm{E}-03$ \\
Marine eutrophication & $\mathrm{t} \mathrm{N}$ & $8.60 \mathrm{E}-04$ \\
Metal depletion & $\mathrm{t} \mathrm{Fe}$ & $1.80 \mathrm{E}-04$ \\
Natural land transformation & $\mathrm{m}^{2}$ & $1.76 \mathrm{E}-04$ \\
Ozone depletion & $\mathrm{t} \mathrm{CFC-11}$ & $1.19 \mathrm{E}-07$ \\
Particulate matter formation & $\mathrm{t} \mathrm{PM10}$ & $7.70 \mathrm{E}-04$ \\
Photochemical oxidant formation & $\mathrm{t} \mathrm{NMVOC}$ & $7.16 \mathrm{E}-03$ \\
Terrestrial acidification & $\mathrm{t} \mathrm{SO} 2$ & $1.56 \mathrm{E}-03$ \\
Terrestrial ecotoxicity & $\mathrm{t} 1,4-\mathrm{DCB}$ & $1.10 \mathrm{E}-04$ \\
Urban land occupation & $\mathrm{m}^{2} \mathrm{a}$ & 0.04 \\
Water depletion & $\mathrm{m}$ & 5.18 \\
\hline
\end{tabular}


Table 9. Comparison effects amongst without and with Brillante $\mathrm{CO}_{2}$-EOR project.

\begin{tabular}{|c|c|c|c|c|}
\hline & & Unit & $\begin{array}{l}\text { Without } \\
\text { project }\end{array}$ & $\begin{array}{l}\text { With } \\
\text { project }\end{array}$ \\
\hline $\mathrm{CO}_{2}$ vented in the Ammonia plant (Four) & $\mathrm{a}$ & $\mathrm{t} / \mathrm{d}$ & 4632 & \\
\hline $\mathrm{CO}_{2}$ injected Brillante field & $\mathrm{b}$ & $t / d$ & 0 & $834^{\mathrm{a}}$ \\
\hline Duration of EOR operation & $\mathrm{c}$ & $\mathrm{y}$ & & $9^{\mathrm{a}}$ \\
\hline Total $\mathrm{CO}_{2}$ injected during EOR operation & $\mathrm{d}=\mathrm{b} \cdot 365^{\circ} \mathrm{c}$ & $\mathrm{t}$ & 0 & $2,739,690$ \\
\hline $\mathrm{CO}_{2}$ storage & $\mathrm{e}$ & $t / d$ & 0 & $417^{\mathrm{a}}$ \\
\hline Anual $\mathrm{CO}_{2}$ storage & $f=e \cdot 365$ & $t / y$ & 0 & 152,205 \\
\hline Total $\mathrm{CO}_{2}$ storage during EOR operation & $g=f \bullet c$ & $\mathrm{t}$ & 0 & $1,369,845$ \\
\hline Additional oil recovered by EOR & $\mathrm{h}$ & $\mathrm{bbl} / \mathrm{d}$ & 0 & $5,900^{\mathrm{a}}$ \\
\hline Oil production ratio/EOR process efficiency & $\mathrm{i}=\mathrm{h} / \mathrm{b}$ & $\mathrm{bbl} / \mathrm{tCO}_{2}$ & 0 & 7.07 \\
\hline $\begin{array}{l}\text { Net increase in oil production as a result of } \\
\text { EOR operation }\end{array}$ & $\mathrm{j}^{\mathrm{a}}$ & bbl & 0 & $5,200,000$ \\
\hline Storage factor $\mathrm{CO}_{2}$ & $\mathrm{k}=\mathrm{g} / \mathrm{j}$ & $\mathrm{tCO}_{2} / \mathrm{bbl}$ & 0 & 0.263 \\
\hline Emissions of oil field operations & 1 & $\mathrm{tCO}_{2 \mathrm{e}} / \mathrm{bbl}$ & 0 & 0.060 \\
\hline Net storage factor & $\mathrm{m}=\mathrm{k}-\mathrm{l}$ & $\mathrm{kgCO}_{22} / \mathrm{bbl}$ & 0 & 203.4 \\
\hline Price one barrel & $\mathrm{n}$ & USD/bbl & 0 & 25 \\
\hline Economic benefits by selling additional oil & $\mathrm{o}=\mathrm{j} \bullet \mathrm{n}$ & MUSD & 0 & 130 \\
\hline Energy of one barrel oil & $\mathrm{p}$ & $\mathrm{MJ} / \mathrm{bbl}$ & 0 & 6,382 \\
\hline Produce primary energy by EOR & $p=j \bullet p$ & TJ & 0 & 33,186 \\
\hline Energy needed to capture one ton of $\mathrm{CO}_{2}$ & $\mathrm{r}$ & $\mathrm{MJ} / \mathrm{tCO}_{2}$ & 1350 & ---- \\
\hline $\begin{array}{l}\text { Total loss energy by vented } \mathrm{CO}_{2} \text { from } \\
\text { ammonia plant }\end{array}$ & $s=a-b \cdot r \cdot 365 \bullet c$ & TJ & 16751 & ---- \\
\hline $\begin{array}{l}\text { Successful use of energy of } \mathrm{CO}_{2} \text { from } \\
\text { ammonia plan during EOR operation }\end{array}$ & $\mathrm{t}=\mathrm{b} \cdot \mathrm{r} \bullet 365 \bullet \mathrm{c}$ & TJ & 0 & 3,699 \\
\hline Net energy generated by the EOR project & $\mathrm{u}=\mathrm{p}-\mathrm{t}$ & $\mathrm{TJ}$ & 0 & 29,488 \\
\hline Energy generated/EOR process efficiency & $v=i \bullet p$ & $\mathrm{TJ} / \mathrm{tCO}_{2}$ & 0 & 0.045 \\
\hline
\end{tabular}

${ }^{\mathrm{a}}$ Arteaga-Cardona et al. (2015); ${ }^{\mathrm{b}}$ Own estimates for Brillante field

Table 10. Key findings

\begin{tabular}{lcc}
\hline \multicolumn{1}{c}{$\mathrm{CO}_{2}$-EOR performance } & Unit & Value \\
\hline Gross sequestration benefit & $\mathrm{tCO} / \mathrm{bbl}$ oil produced & 0.203 \\
Energy consumption & $\mathrm{MJ}$ per $\mathrm{MJ}$ oil produced & 0.010 \\
Energy for $\mathrm{CO}_{2}$ capture from ammonia plant & $\mathrm{MJ} / \mathrm{kgCO}_{2}$ & 1.35 \\
Incremental oil produced & $\mathrm{Mbbl}$ & 5.2 \\
Energy generated/EOR process efficiency & $\mathrm{TJ} / \mathrm{tCO}_{2}$ injected & 0.045 \\
\hline
\end{tabular}




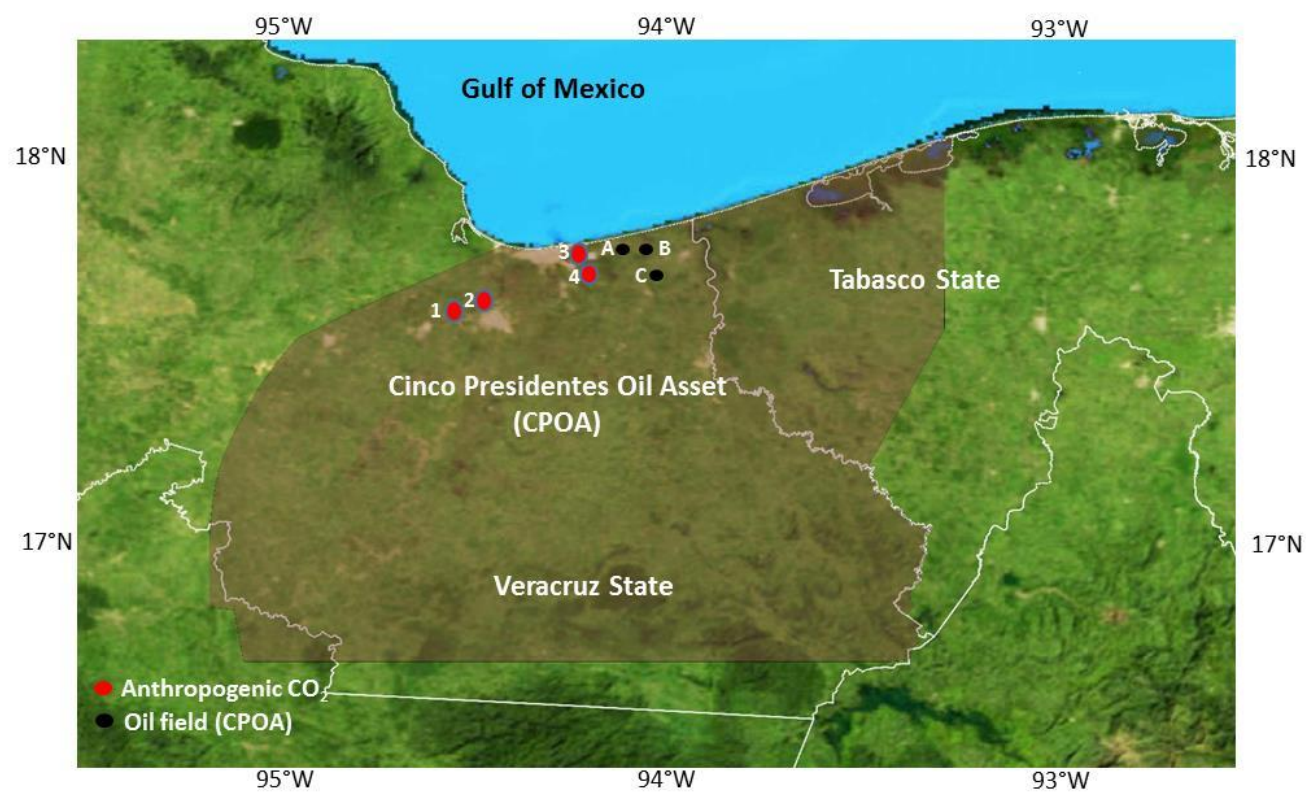

Figure 1. Sources of anthropogenic $\mathrm{CO}_{2}$ (1: Cosoleacaque Petrochemical Complex (CPC); 2: Minatitlán Refinery; 3: Morelos PQC and Cangrejera PQC) and oil fields (A: Brillante; B: Rabasa and C: Los Soldados)

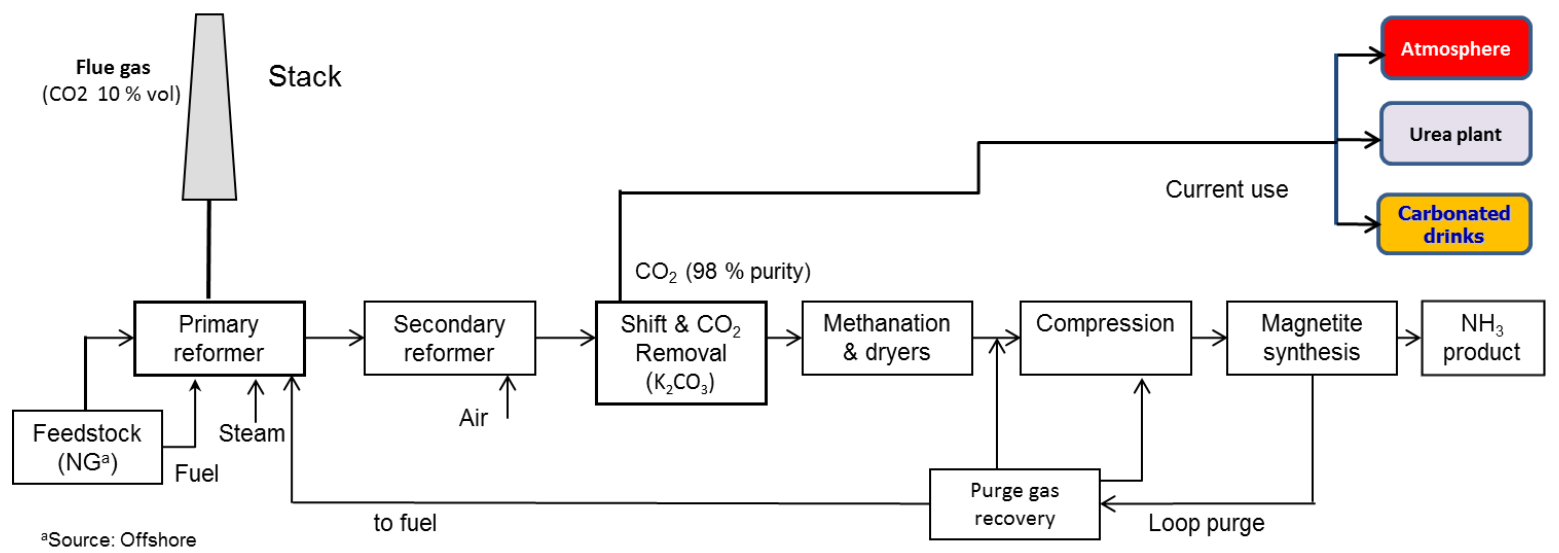

Figure 2. General process flow of typical synthesis ammonia, sources of $\mathrm{CO}_{2}$ emissions and uses in the case of the CPC 


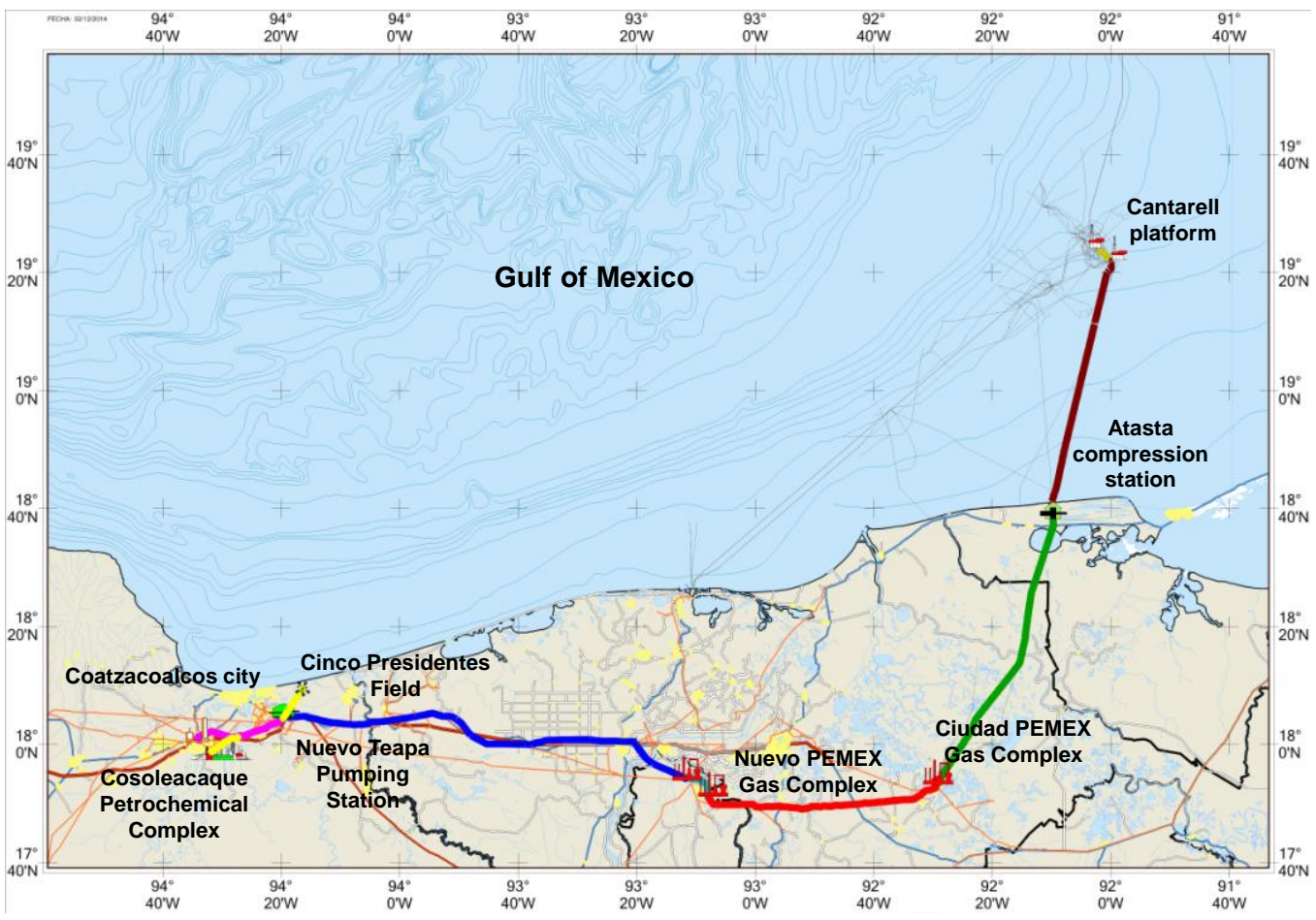

Figure 3. Study area, trajectory and distance $(500 \mathrm{~km})$ from pipeline 


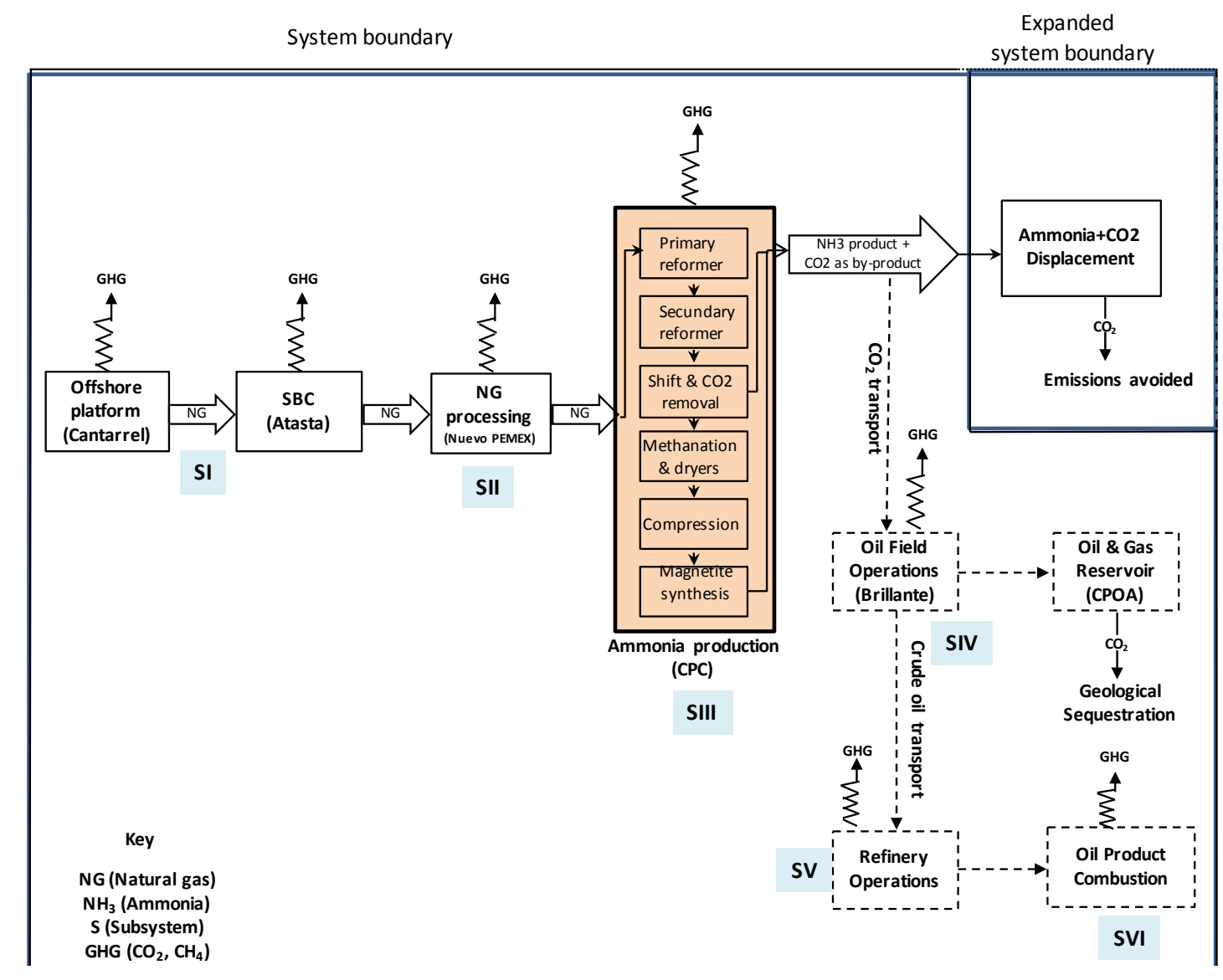

Figure 4. System boundary for Brillante $\mathrm{CO}_{2}$-EOR project using $\mathrm{CO}_{2}$ derived from ammonia process for EOR

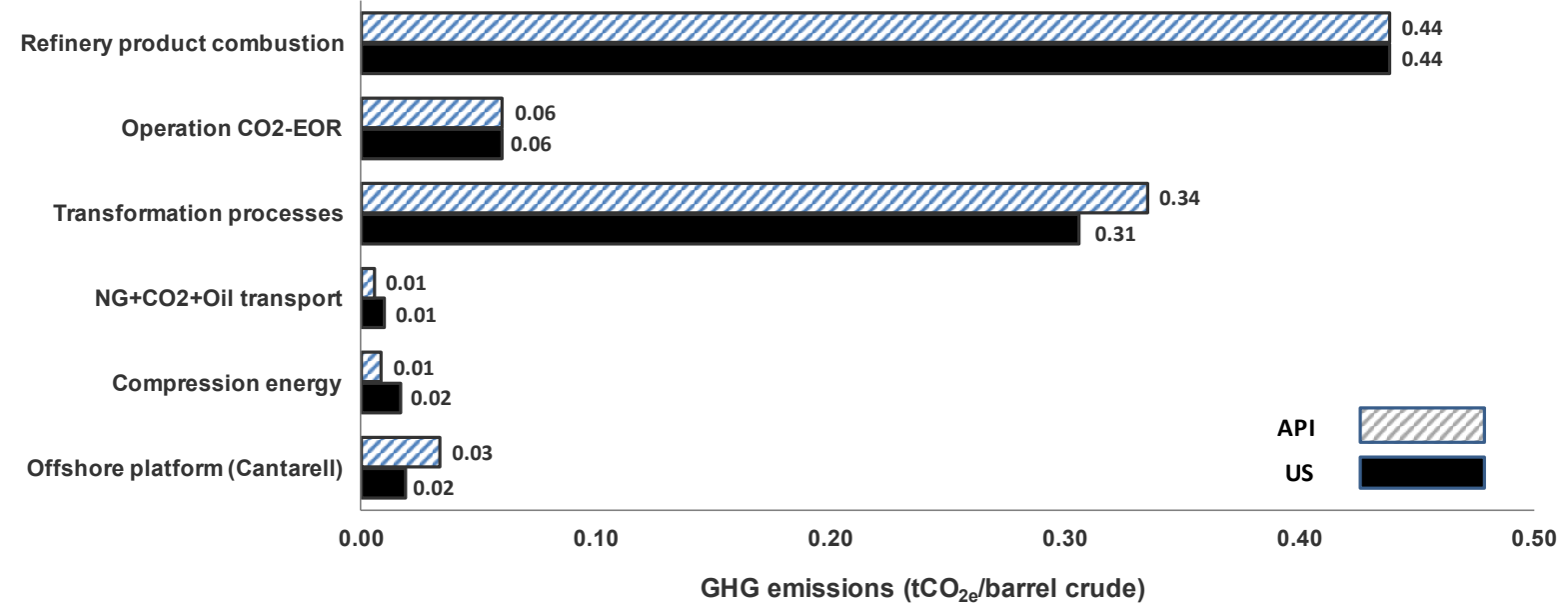

Figure 5. Contribution lice cycle GHG emissions of main activities 


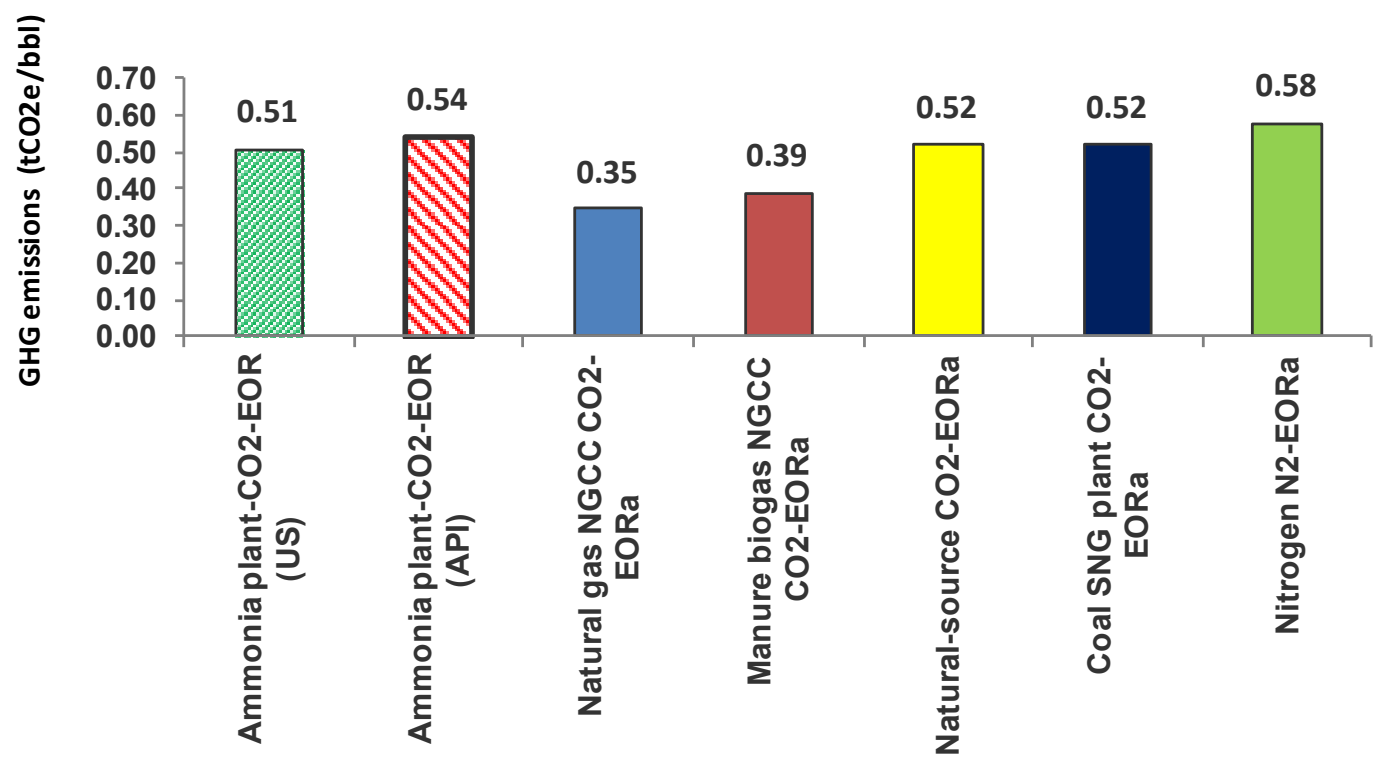

a:Hussaint et al. (2013)

Figure 6. Comparison results amongst this study versus lifecycle GHG emissions per barrel of oil extracted using different EOR methods

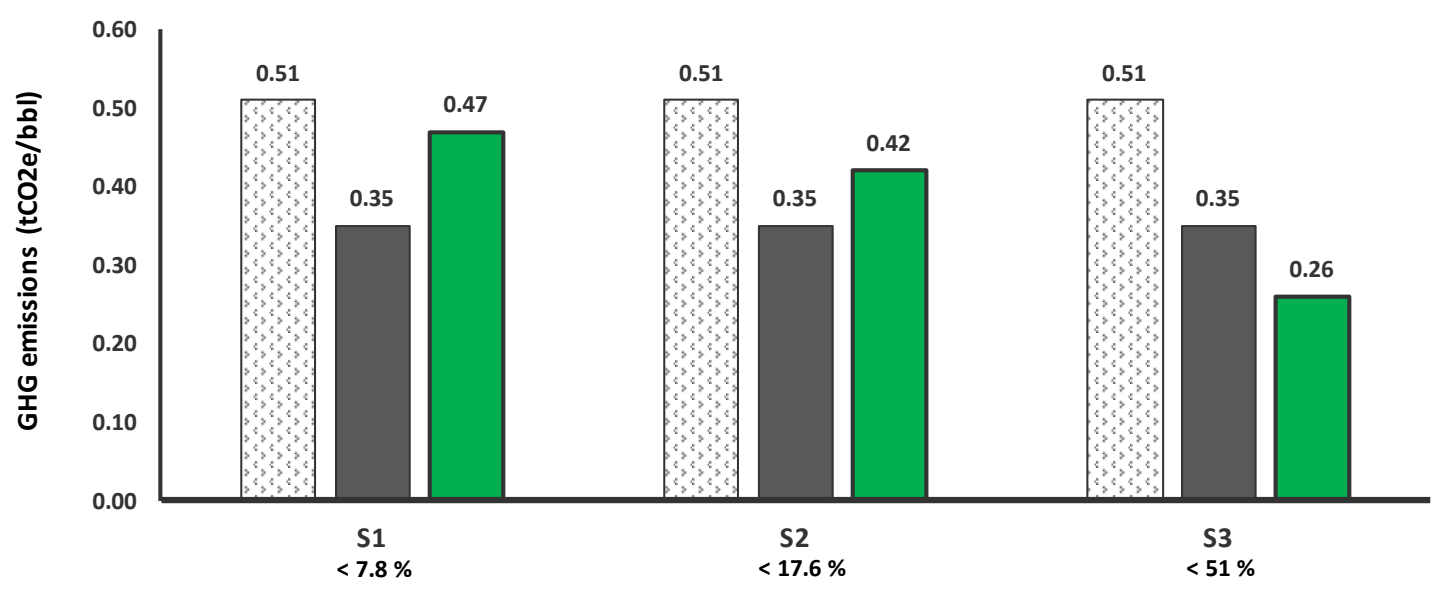

Ammonia plant-CO2-EOR (US:Base case)

$\square$ Natural gas NGCC CO2-EORa (Hussaint et al. 2013)

Ammonia plant-CO2-EOR (SA)

Figure 7. Effects of GHG emissions results for oil field operation (S1), geological sequestration (S2) and $\mathrm{CO}_{2}$ capture from flue gas ammonia plant (S3) using different perspectives 